\title{
(1) aramantar \\ Clinical course of sly syndrome (mucopolysaccharidosis type VII)
}

\author{
Adriana M Montaño, ${ }^{1,2}$ Ngu Lock-Hock, ${ }^{3}$ Robert D Steiner, ${ }^{4,5,6}$ Brett $\mathrm{H} \mathrm{Graham}^{7}$ \\ Marina Szlago, ${ }^{8}$ Robert Greenstein, ${ }^{9}$ Mercedes Pineda, ${ }^{10}$ Antonio Gonzalez-Meneses, ${ }^{11}$ \\ Mahmut Çoker, ${ }^{12}$ Dennis Bartholomew, ${ }_{1}^{13}$ Mark S Sands, ${ }_{1}^{14}$ Raymond Wang, ${ }^{15,16}$ \\ Roberto Giugliani, ${ }^{17}$ Alfons Macaya, ${ }^{18}$ Gregory Pastores, ${ }_{1}^{19}$ Anastasia K Ketko, ${ }^{20,21}$ \\ Fatih Ezgü, ${ }^{22}$ Akemi Tanaka, ${ }^{23}$ Laila Arash, ${ }^{24}$ Michael Beck, ${ }^{24}$ Rena E Falk, ${ }_{1}^{25}$ \\ Kaustuv Bhattacharya ${ }^{26}$ José Franco, ${ }^{27}$ Klane K White, ${ }^{28}$ Grant A Mitchell, ${ }^{29}$ \\ Loreta Cimbalistiene, ${ }^{30}$ Max Holtz, ${ }^{31}$ William S Sly ${ }^{2}$
}

For numbered affiliations see end of article.

\section{Correspondence to Dr Adriana M Montaño, Doisy Research Center, Department of Pediatrics, Saint Louis University, 1100 South Grand Blvd., Room 311, St. Louis, MO 63104, USA; montana@slu.edu}

Dr Tanaka died on 11 July 2015.

Received 14 July 2015 Revised 4 January 2016 Accepted 10 January 2016 Published Online First 23 February 2016

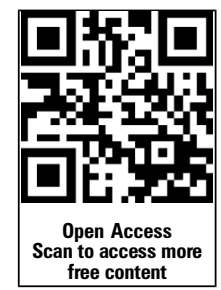

CrossMark

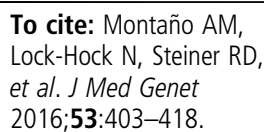

\section{ABSTRACT}

Background Mucopolysaccharidosis VII (MPS VII) is an ultra-rare disease characterised by the deficiency of $\beta$ glucuronidase (GUS). Patients' phenotypes vary from severe forms with hydrops fetalis, skeletal dysplasia and mental retardation to milder forms with fewer manifestations and mild skeletal abnormalities. Accurate assessments on the frequency and clinical characteristics of the disease have been scarce. The aim of this study was to collect such data.

Methods We have conducted a survey of physicians to document the medical history of patients with MPS VII. The survey included anonymous information on patient demographics, family history, mode of diagnosis, age of onset, signs and symptoms, severity, management, clinical features and natural progression of the disease. Results We collected information on 56 patients from 11 countries. Patients with MPS VII were classified based on their phenotype into three different groups: (1) neonatal non-immune hydrops fetalis (NIHF) $(n=10)$, (2) Infantile or adolescent form with history of hydrops fetalis ( $n=13$ ) and (3) Infantile or adolescent form without known hydrops fetalis $(n=33)$. Thirteen patients with MPS VII who had the infantile form with history of hydrops fetalis and survived childhood, had a wide range of clinical manifestations from mild to severe. Five patients underwent bone marrow transplantation and one patient underwent enzyme replacement therapy with recombinant human GUS.

Conclusions MPS VII is a pan-ethnic inherited lysosomal storage disease with considerable phenotypical heterogeneity. Most patients have short stature, skeletal dysplasia, hepatosplenomegaly, hernias, cardiac involvement, pulmonary insufficiency and cognitive impairment. In these respects it resembles MPS I and MPS II. In MPS VII, however, one unique and distinguishing clinical feature is the unexpectedly high proportion of patients (41\%) that had a history of NIHF. Presence of NIHF does not, by itself, predict the eventual severity of the clinical course, if the patient survives infancy.

\section{INTRODUCTION}

Mucopolysaccharidosis VII (Sly syndrome; MPS VII) is an autosomal recessive lysosomal storage disorder
(LSD) that is characterised by the deficiency of activity of $\beta$-glucuronidase (GUS: $\beta$-D-glucuronoside glucuronosohydrolase, Enzyme Commission (EC) number: 3.2.1.31; GUSB: MIM 611499)..$^{12}$ GUS is one of the enzymes involved in the stepwise degradation of three glycosaminoglycans (GAGs). In the absence of GUS, chondroitin sulfate, dermatan sulfate and heparan sulfate are only partially degraded and the partially degraded fragments accumulate in the lysosomes of many tissues, eventually leading to cellular and organ dysfunction.

MPS VII is an ultra-rare disorder and precise epidemiological data are scarce. In an epidemiological study of the MPS population in northern Ireland from 1948 to 1985 , Nelson reported three cases of fatal non-immune hydrops fetalis (NIHF) in infants born to consanguineous parents that were believed to be MPS VII due to GUS deficiency on the basis of placental histology and enzyme assays of both parents. However no living cases of MPS VII were reported. ${ }^{3}$ In the 1970 s a total of 10 cases of MPS VII were reported in the literature. ${ }^{1}$ 4-9 Subsequently, Meikle reported two patients born with MPS VII from 1980 to 1996 in Australia ${ }^{10}$ and Applegarth reported three cases in British Columbia from 1969 to $1996 .^{10}{ }^{11}$ In The Netherlands, Poorthuis reported six cases of patients born with MPS VII from 1985 to $1995 .^{12}$ No cases were reported in Germany (1980-1995), Scandinavian countries (1975 and 2004), Taiwan (1984-2004) and western Australia (1969_ 1996). ${ }^{13-16}$ Recently one more case with hydrops fetalis was reported in Germany. ${ }^{17}$ Overall the frequency of this disease is estimated to be 1:300 000-1:2 $000000 .{ }^{18}$ Many patients may have been missed because of early death in utero since the most frequent phenotype may be hydrops fetalis in the antenatal form. ${ }^{12} 1{ }^{19-21}$ Others may have died in early infancy without diagnosis.

The GUS gene is located on chromosome $7 \mathrm{q} 11.21-7 \mathrm{q} 11.22$ spanning $20 \mathrm{~kb}$ and containing 12 exons. $^{22}$ Isolation and characterisation of the human GUS cDNA facilitated the investigation of allelic heterogeneity in patients with MPS VII. ${ }^{23-27}$ To date 49 unique, disease-causing mutations have been reported in patients with MPS VII. Mutations 
are distributed along the whole gene and include missense mutations $(78.6 \%)$, nonsense mutations $(12.6 \%)$, deletions $(5.8 \%)$ and splice-site mutations (2.9\%). ${ }^{28-32}$ In addition to reports of disease-causing mutations, there are two reports of a pseudo-GUS deficiency where obligate heterozygotes have unusually diminished enzyme activity, and increased excretion of urinary GAGs without pathological manifestations. ${ }^{33} 34$ Clinical severity observed in patients with MPS VII and the correlation with their genotype currently remains an important area of investigation.

The clinical presentation and disease progression of MPS VII span a wide severity spectrum. Most patients with MPS VII have cognitive impairment, hepatosplenomegaly and skeletal dysplasia. However, affected patients show a wide range of clinical variability, from early, severe, multisystem manifestations to a milder phenotype with later onset and normal or near-normal intelligence. Although patients with MPS VII may present with hydrops fetalis at birth and only survive a few months, rare patients with milder manifestations of MPS VII have survived into the fifth decade of life. ${ }^{2} 4$

As with other MPS diseases, as more patients were identified, it became clear that there is a broad spectrum or continuum of disease severity among patients with MPS VII. To date, accurate assessments of the frequency and clinical characteristics of the disease have been difficult. Gathering data on the natural history of MPS VII was needed to understand more fully the spectrum of disease severity, and the rate of progression and distribution of specific symptoms in untreated patients with MPS VII. In this study, data were collected on disease severity, the rate of progression and distribution of specific symptoms in untreated patients with MPS VII. These data are important to enable early detection, to define potential clinical end points and to provide comparative data to judge the effects of future treatments.

\section{SUBJECTS AND METHODS}

\section{Survey and study population}

A survey was developed to document the medical history of patients with MPS VII. The survey included anonymous information on patient demographics, family history, mode of diagnosis, age of onset, signs and symptoms, severity, management, clinical features and natural progression of the disease. The survey was administered to physicians who currently or previously cared for patients with MPS VII. The database of physicians was provided by Engage Health and an email was designed to recruit physicians from all over the world. All physicians who participated were contacted by phone and each interview lasted approximately $1 \mathrm{~h}$. Since the information obtained was anonymous and no protected health information was collected, Institutional Review Board (IRB) approval was not obtained. Information was collected on 56 patients from 11 countries. Data were collected from 23 physicians from North and South America, Europe, Asia and Oceania. The survey was conducted in English and/or Spanish. On each item, physicians responded: yes, no, or not reported in patient's record. From the items with informative responses (yes/ no) we calculated the percentage for each answer.

\section{Alignment of sequences}

Multiple amino acid alignment of GUS sequences from human, chimpanzee, cow, pig, dog, mouse, rat, chicken, frog, fruit fly, mosquito, honey bee, red flour beetle, Gram-positive bacteria and enterobacteria was constructed by using ClustalW Multiple alignment application on BioEdit program $^{35}$ with manual adjustment. The final selected alignment was converted to
Molecular Evolutionary Genetics Analysis (MEGA) 4. ${ }^{36}$ GenBank reference sequences: Homo sapiens, NM_000181.3; Pan troglodytes, XM_001138883.4; Bos taurus, NM_001083436; Sus scrofa, AK232674; Canis lupus familiaris, NP_001003191.1; Mus musculus, NP 034498; Rattus norvegicus, NP 058711; Gallus gallus, NP 001034405.1; Xenopus tropicalis, CT̄030620; Drosophila melanogaster, NP 001014535.1; Anopheles gambiae, XP_320660.4; Apis mellifera, XM_393305; Tribolium castaneum, XM 964260; Arthrobacter Sp. RP 10, AAV91790; and Escherichia coli, AAB30197.

\section{Data handling and analysis}

After the information was collected, all surveys were compiled in a database for statistical analyses. Although all the information from physicians was compiled, information on some items could not be obtained. Variables were summarised using descriptive statistics including mean, median, ranges, percentages and/ or frequencies. All analyses were performed using SPSS for windows (IBM SPSS Statistics for Windows, V.20.0. Armonk, New York: IBM Corp).

Table 1 Demographics of patients with MPS VII $(n=56)$

\begin{tabular}{|c|c|c|}
\hline & Statistics & Value \\
\hline Number enrolled & $\mathrm{n}$ & 56 \\
\hline \multicolumn{3}{|l|}{ Gender } \\
\hline Male & & $30(53 \%)$ \\
\hline Female & & $20(36 \%)$ \\
\hline Unknown* & & $6(11 \%)$ \\
\hline \multicolumn{3}{|l|}{ Ethnicity } \\
\hline Caucasian-Non-Hispanic & $\mathrm{n}(\%)$ & $35(62 \%)$ \\
\hline Caucasian-Hispanic & $\mathrm{n}(\%)$ & $10(18 \%)$ \\
\hline Black or African-American & $\mathrm{n}(\%)$ & $5(9 \%)$ \\
\hline Asian & $\mathrm{n}(\%)$ & $4(7 \%)$ \\
\hline Native Hawaiian or other Pacific Islander & $\mathrm{n}(\%)$ & $1(2 \%)$ \\
\hline Other & $\mathrm{n}(\%)$ & $1(2 \%)$ \\
\hline \multicolumn{3}{|l|}{ Country } \\
\hline Brazil & $\mathrm{n}(\%)$ & $15(27 \%)$ \\
\hline USA & $\mathrm{n}(\%)$ & $11(20 \%)$ \\
\hline Germany & $\mathrm{n}(\%)$ & $10(18 \%)$ \\
\hline Argentina & $\mathrm{n}(\%)$ & $6(11 \%)$ \\
\hline Spain & $n(\%)$ & $4(7 \%)$ \\
\hline Turkey & $\mathrm{n}(\%)$ & $3(5 \%)$ \\
\hline Japan & $\mathrm{n}(\%)$ & $2(3 \%)$ \\
\hline Malaysia & $\mathrm{n}(\%)$ & $2(3 \%)$ \\
\hline Mexico & $\mathrm{n}(\%)$ & $1(2 \%)$ \\
\hline Australia & $\mathrm{n}(\%)$ & $1(2 \%)$ \\
\hline Lithuania & $\mathrm{n}(\%)$ & $1(2 \%)$ \\
\hline \multicolumn{3}{|l|}{ Age at the last visit to the physician } \\
\hline & Min & 0.3 \\
\hline & Max & 30 \\
\hline & Mean & 13.25 \\
\hline & Median & 11 \\
\hline & Range & 29.7 \\
\hline & Kurtosis & -1.11 \\
\hline \multicolumn{3}{|l|}{ Status at time of interview } \\
\hline Living & n (\%) & $30(53 \%)$ \\
\hline Deceased & n (\%) & $20(36 \%)$ \\
\hline Unknownt & $\mathrm{n}(\%)$ & $6(11 \%)$ \\
\hline
\end{tabular}




\section{RESULTS AND DISCUSSION}

\section{Patient demographics}

Our survey collected data on 56 patients of whom 53\% were boys, 36\% girls and 11\% sex-unknown (diagnosed in utero). Sixty-two per cent of the patients were Caucasian. The other patients were of white-Hispanic (18\%), black (9\%), Asian (7\%) and other (4\%) origin. The geographical distribution of patients with MPS VII (table 1) showed they were predominantly from Brazil (27\%), USA (20\%), Germany (18\%) and Argentina (11\%). The high percentage of patients from Latin America may reflect ascertainment bias because of national practices of referring all patients with lysosomal storage diseases to key treatment centres.

Information on patient age at the last visit to the physician was collected in 28 patients (table 1 ). The mean age distribution at the last visit to the physician was 13.25 years, the median was 11 years and the distribution of the ages was wide. Fifty-three per cent of the patients were still living at the time of the physician interview.

\section{Diagnosis and presentation of the disease}

Thirty-four per cent of the patients were diagnosed prenatally or below 1 year of age, $16 \%$ from 1 year to 3 years of age, $11 \%$ from 3 years to 5 years of age, 20\% from 5 years to 10 years of age and $12 \%$ over 10 years of age. Age at time of initial diagnosis in $7 \%$ of the patients was unknown.

Patients with MPS VII were classified based on their phenotype into three different groups: (1) non-immune neonatal hydrops fetalis (NIHF) $(n=10),(2)$ Infantile or adolescent form with history of hydrops fetalis $(n=13)$ and (3) Infantile or adolescent form without known hydrops fetalis $(n=33)$. Thirteen patients with MPS VII who had the infantile form with history of hydrops fetalis and survived childhood, had a range of clinical manifestations from mild to severe, suggesting that presence of hydrops fetalis does not necessarily predict the subsequent severity of the disease (figure 1).

\section{Clinical characteristics of patients with infantile or adolescent form of the disease}

Distribution of clinical symptoms was tabulated for 46 patients with MPS VII, of whom 13 had a history of hydrops. From the items with informative responses (yes/no), we calculated the percentage, and the number of informative responses varies for each item as noted in each figure.

Head, eyes, ear-nose-throat (ENT) (figure 2): Coarse facial features were reported in $87 \%$ of patients, $87 \%$ had increased cranial circumference and $78 \%$ had a short neck (figure $2 \mathrm{~A}$ ). Coarse hair was noted in $60 \%$ of the patients.

The predominant ocular features were corneal clouding (63\%), heavy eyebrows (52\%), visual impairment $(37 \%)$ and photosensitivity (30\%) (figure 2B). A majority of patients had ear $(52 \%)$ and respiratory (69\%) infections, enlarged tongue (64\%), which is associated with snoring (68\%), abnormal dentition (50\%) with small and widely spaced teeth (57\%), and gingival hypertrophy (57\%). Sensorineural hearing loss was observed in $41 \%$ of the patients (figure 2C).

Lungs and heart (figure 3): Clinical symptoms related to the respiratory system included decreased pulmonary function (71\%), obstructive airway disease (44\%), sleep apnoea (35\%) and chronic bronchitis (29\%). Heart abnormalities included cardiac valve disease (50\%) and cardiomyopathies (37\%).

Musculoskeletal (figure 4): Dysostosis multiplex on X-ray (90\%) was the most consistent finding in the MPS VII patient survey. Next was loss of joint range of motion $(85 \%)$, giving rise to restricted mobility $(78 \%)$, joint contractures $(84 \%)$ and stiffness (72\%). Spine deformities included scoliosis $(69 \%)$, kyphosis (68\%) and gibbus (63\%). Leg deformities included genu valgum (63\%) and talipes equinovarus (35\%). Hand
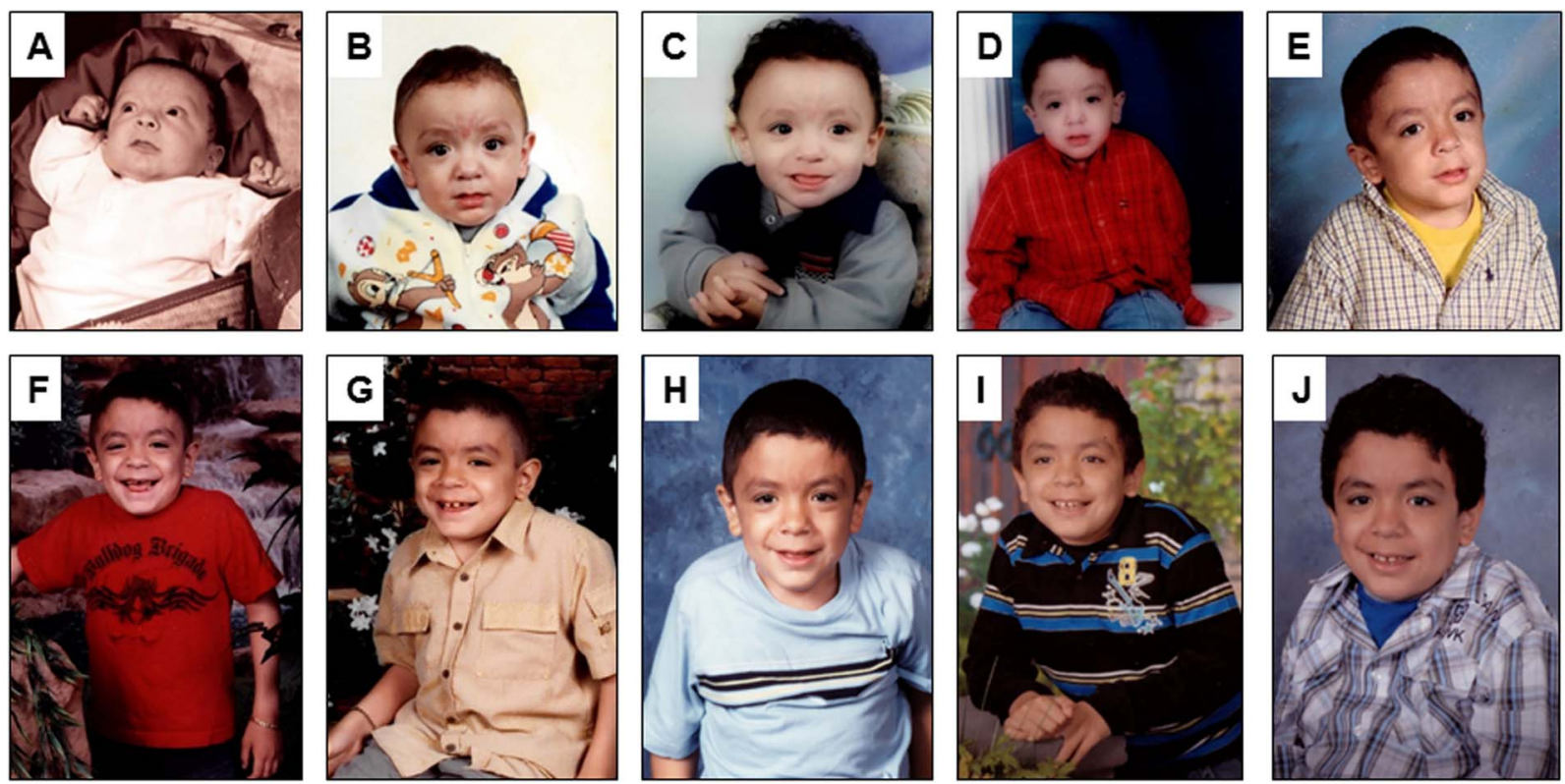

Figure 1 Serial pictures of a male patient who survived a stormy early course, beginning with neonatal hydrops and subsequently progressed more slowly with cognitive impairment, hepatosplenomegaly, obstructive airway disease, heart valve abnormalities and dysostosis multiplex including progressive hip dysplasia. This patient died undergoing anaesthesia from a dental procedure at age 12 years, which is a complication from which these patients often suffer. (A) 2.5 months old, (B) 6 months old, (C) 1 year old, (D) 3 years old, (E) 5 years old, (F) 6 years old, (G) 7 years old, (H) 8 years old, (I) 9 years old and (J) 11 years old. Photographs of the deceased patient were obtained and approved for publication with maternal consent. X-rays are shown below in the section clinical course of the disease (figures 12 and 13). 


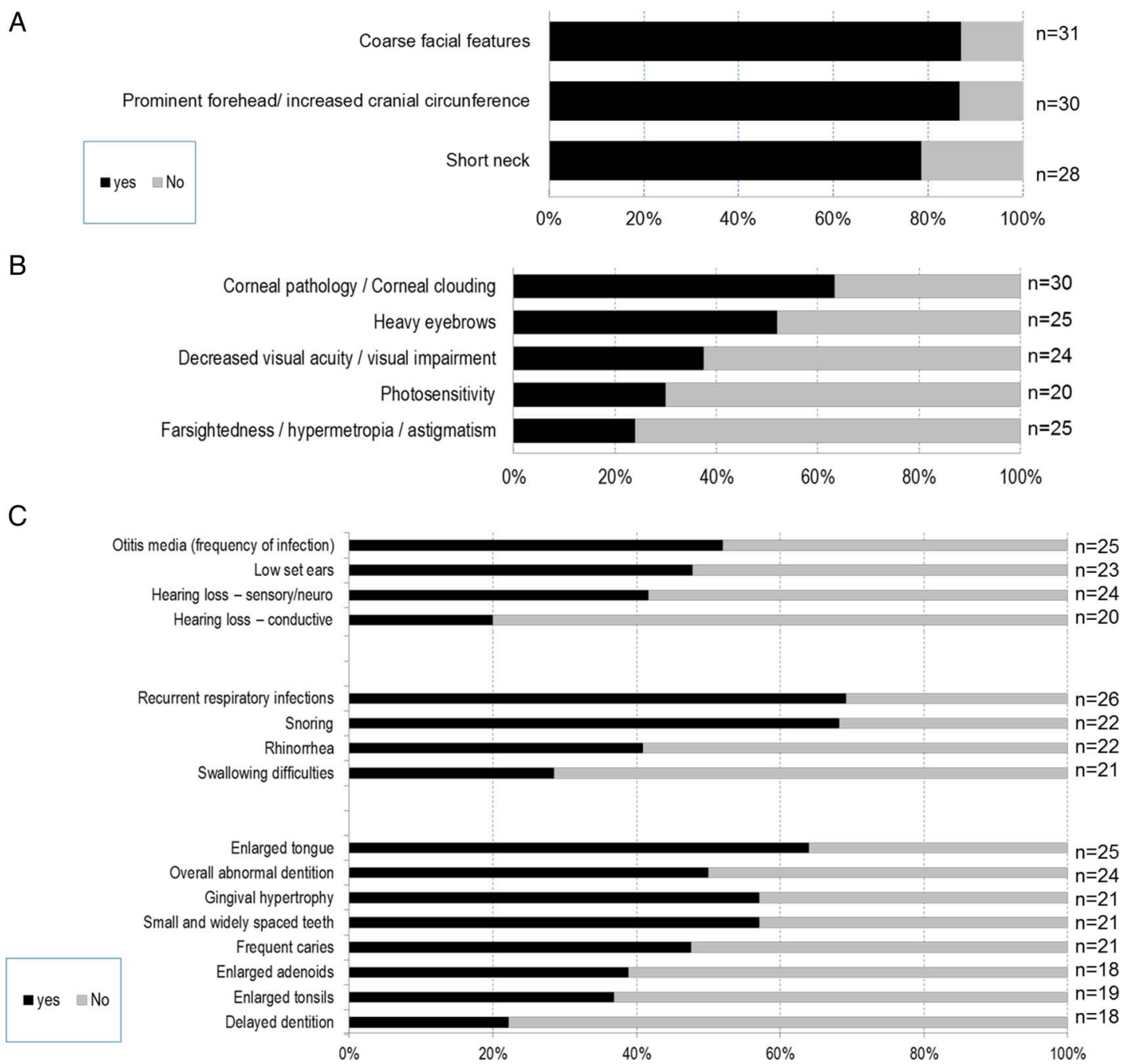

Figure 2 Clinical symptoms found in (A) head and neck, (B) eyes, and (C) ear, nose and throat of patients with mucopolysaccharidosis VII (MPS VII) disease.

abnormalities included a decreased range of wrist motion (58\%), clawed hands (56\%) and curved fingers (54\%). Acetabular dysplasia in hips was observed in $53 \%$ of the patients and $63 \%$ had hip or back pain when bending over.

Thoracolumbar and abdominal abnormalities (figure 5): $88 \%$ of patients had a short trunk, $85 \%$ had pectus carinatum or excavatum, $78 \%$ had rib cage/chest deformities and $79 \%$ had short stature. Additionally, $75 \%$ of patients had hepatomegaly/splenomegaly and $61 \%$ had umbilical and/or inguinal hernias.

Neurological (figure 6): Limited vocabulary (94\%) and mental retardation $(86 \%)$ were the most common neurological problems in patients with MPS VII.

\section{Growth}

Height: Short stature was one of the most characteristic phenotypes observed in patients with MPS VII. In this survey, the preliminary height measurements indicate that patients have normal growth until 18-24 months of age (figure 7A).

In boys we observed scattered values of height (between 5 th and 90th centiles) from 2 years of age to 13 years. Thereafter, we observed a rapid decline in growth (ie, height values compared with normal controls at or below the 5 th centile). In boys at 18 years old, short stature was pronounced. We found a mean height of $151.8 \pm 7.9 \mathrm{~cm}(\mathrm{n}=7)$, corresponding to a $\mathrm{Z}$ score of -3.3 when compared with age-matched Centers for Disease Control and Prevention (CDC) controls (figure 7B).

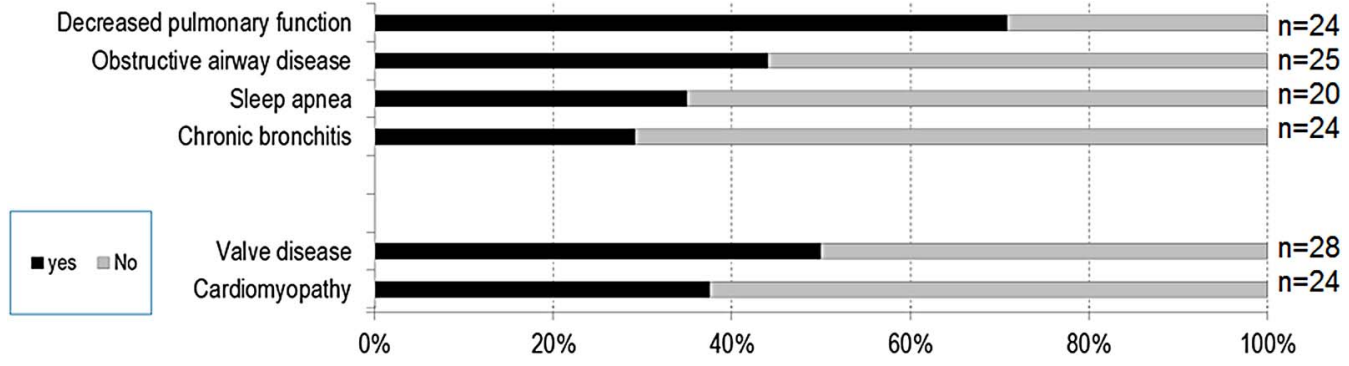

Figure 3 Clinical symptoms related to lungs and heart. 


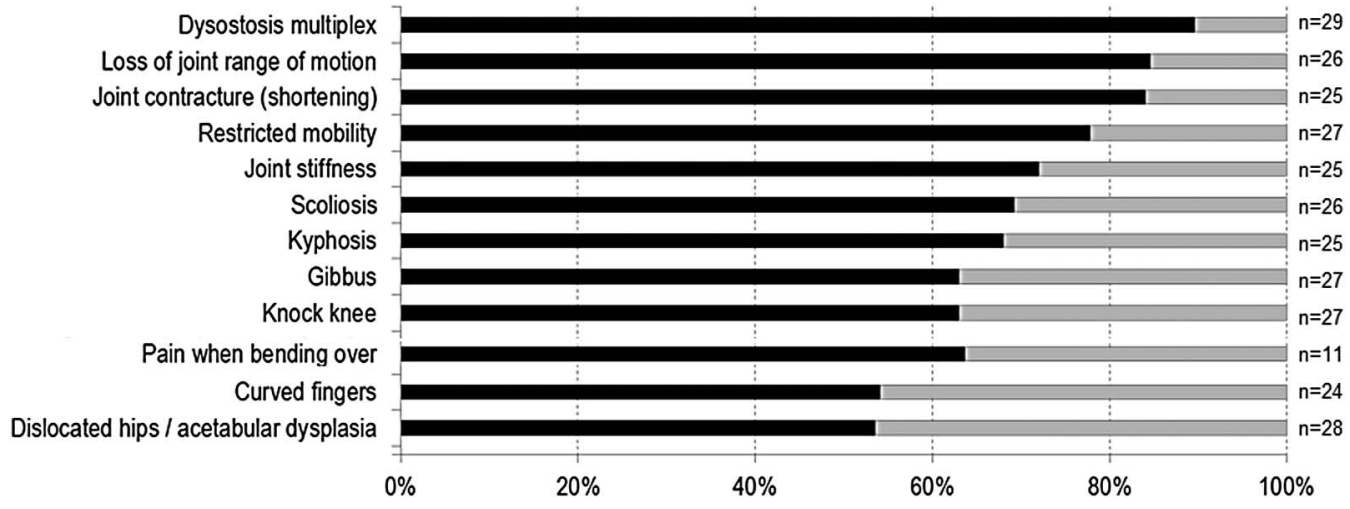

Figure 4 Musculoskeletal signs and symptoms in patients with mucopolysaccharidosis VII (MPS VII).

In girls the short stature was even more extreme. We observed a clear decrease in attained height values when compared with normal controls after 24 months of age with values below the 25 th centile. At 18 years of age the mean height was 114.3 $\pm 25.4 \mathrm{~cm}(\mathrm{n}=5)$, corresponding to a $\mathrm{Z}$ score of -7.8 when compared with age-matched CDC controls (figure 8).

Weight: Comparison of birth weight between patients with MPS VII and age-matched controls found the mean birth weight for boys with MPS VII to be similar $(3.4 \pm 0.6 \mathrm{~kg})(\mathrm{n}=18)$ compared with the CDC control charts for boys $(3.5 \pm 0.5 \mathrm{~kg})$. The mean birth weight for girls with MPS VII was $2.9 \pm 0.7 \mathrm{~kg}$ $(n=5)$, which was slightly lower than the CDC values for girls $(3.4 \pm 0.4 \mathrm{~kg})(\mathrm{Z}$ score $=-1.0)$, the caveat being that the sample size was small (figure 9 ).

At 18 years of age, the mean weight of boys with MPS VII was $50.1 \pm 13.4 \mathrm{~kg}(\mathrm{n}=10)$, which corresponds to a $\mathrm{Z}$ score of -2.1 (2nd centile) (figure 10). The average body mass index (BMI) for boys with MPS VII at $\geq 18$ years was not abnormal: $23.5 \pm 4.8 \mathrm{~kg} / \mathrm{m}^{2} \quad(\mathrm{n}=13)$. One male patient (21 years old) had a very high BMI of $30.2 \mathrm{~kg} / \mathrm{m}^{2}$, which indicated obesity $(96.6$ centile). Four patients of different ages ( 2 years, 4 years, 6 years and 11 years old) had underweight BMIs (figure 10).

In comparison, the mean weight of girls with MPS VII at 18 years of age was $36.2 \pm 12.0 \mathrm{~kg}(\mathrm{n}=4)$, which corresponds to a $\mathrm{Z}$ score of -4.2 (figure 11). The average BMI for girls over 18 years with MPS VII was $23.7 \pm 0.2 \mathrm{~kg} / \mathrm{m}^{2} \quad(\mathrm{n}=8)$; only one female patient (11 years old) had a high BMI of $25.3 \mathrm{~kg} / \mathrm{m}^{2}$ which indicated obesity ( 97.3 centile). Three patients of different ages (4 years, 6 years and 15 years old) had underweight BMIs (figure 11).

\section{Genotype and phenotype}

In this study only $10.7 \%$ of patients with MPS VII $(n=6)$ had mutational analysis, which makes it difficult to describe an accurate correlation between genotype and phenotype (table 2). Three patients had mutations that were previously described (p.L176F, p.R382C, p.P408S and p.P415L) associated with an attenuated phenotype. ${ }^{29}$ The phenotype observed in these patients ranges from mild with mental retardation to severe with moderate mental retardation. One patient was compound heterozygote for the mutation p.D $362 \mathrm{~N}$ which has been associated with a severe phenotype. ${ }^{29}$ However, this patient underwent bone marrow transplantation (BMT, Patient 5), thus association between phenotype and genotype was not possible. Two other patients with severe phenotype were compound heterozygotes for mutations that have not been reported yet (p.D50Y, pV99M, p.W289X and p.L565V), hence detailed correlation between phenotype and genotype has not been defined. Most of the residues that were mutated had a high degree of conservation when compared with sequences of other species (table 2).

\section{Clinical course of the disease}

The first signs and symptoms observed in patients with MPS VII included hydrops fetalis, hernia (umbilical or inguinal), coarse face, hepatosplenomegaly, skeletal dysplasia, heart and respiratory problems, mental retardation, and ear infections. Of the 23 patients with hydrops fetalis in this study, 10 patients had prenatal-onset NIHF. Of those with prenatal-onset hydrops that survived gestation, most died in early infancy of heart, kidney or respiratory failure (table 3). Thirteen patients had the infantile or adolescent form of the disease with history of hydrops fetalis. The 12 patients with the infantile form of the disease who had recovered from hydrops manifested characteristic symptoms of the MPS VII disease, varying from mild to moderate or severe phenotype, as reported by the physicians. This indicates that the presence of neonatal hydrops fetalis does not, by itself, predict the eventual severity of the disease.

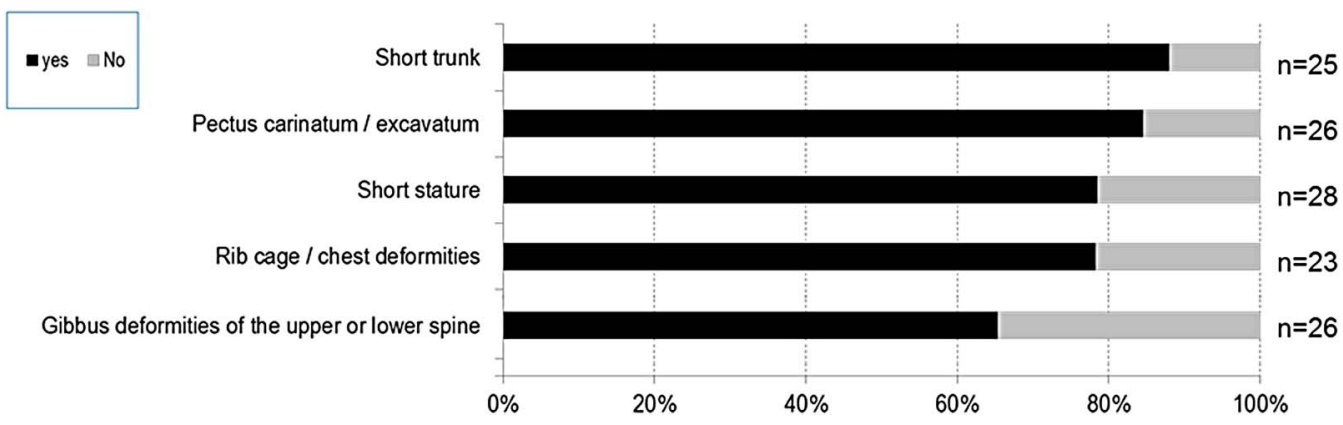

Figure 5 Thoracolumbar abnormalities in patients with mucopolysaccharidosis VII (MPS VII). 
Figure 6 Major neurological features of patients with mucopolysaccharidosis VII (MPS VII).

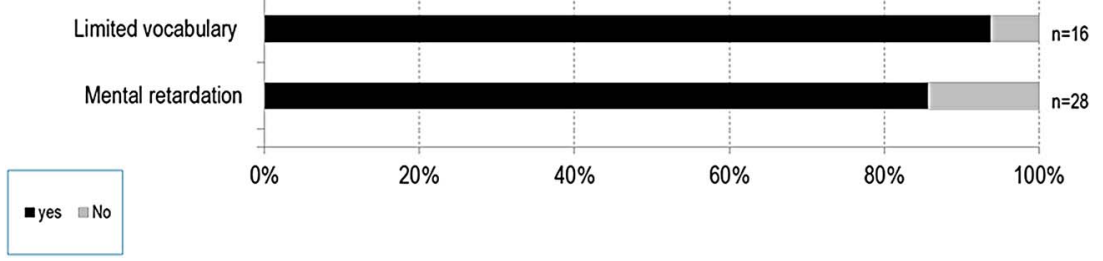

A

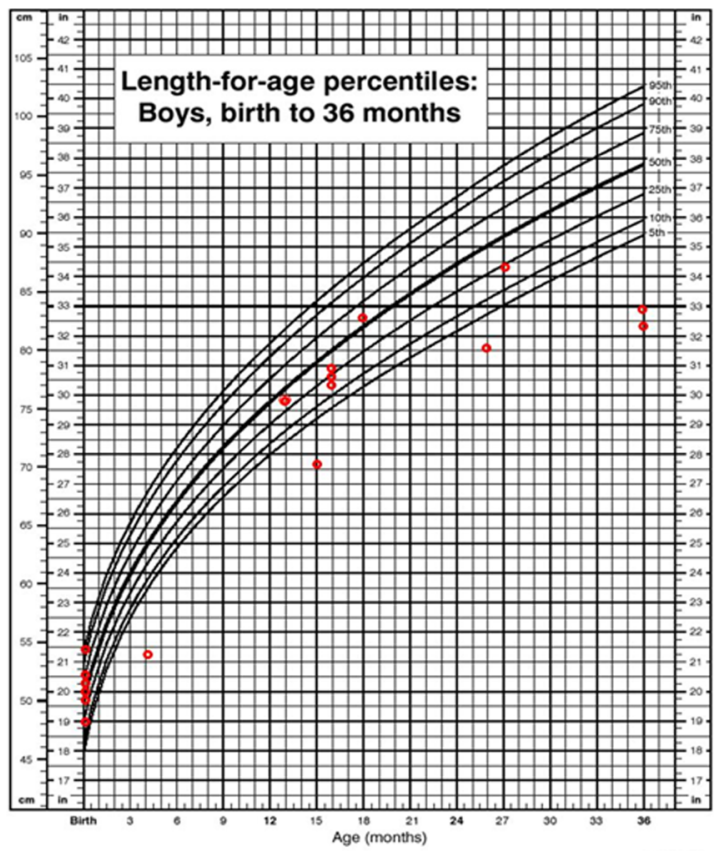

B

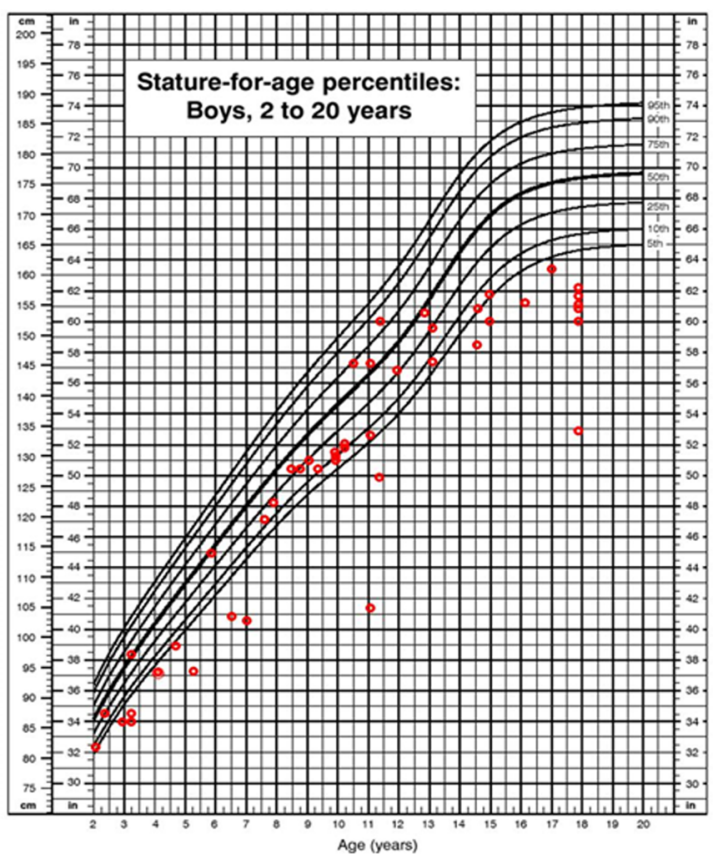

Figure 7 (A) Length for age in boys (0-36 months) affected with mucopolysaccharidosis VII (MPS VII). (B) Stature for age in boys (2-18 years) affected with MPS VII. Data are compared with normal growth charts from the CDC.

A

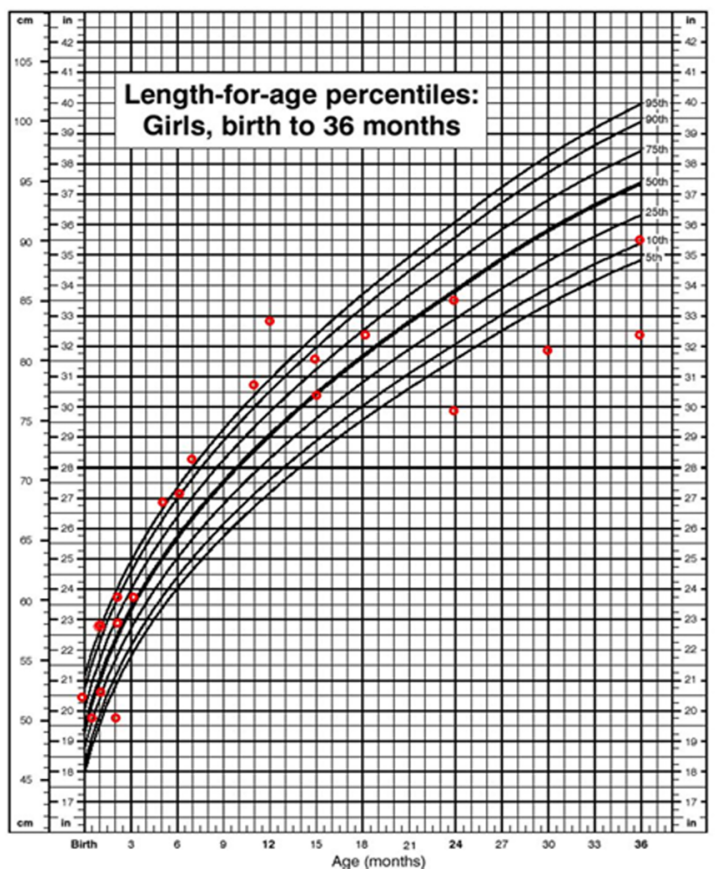

B

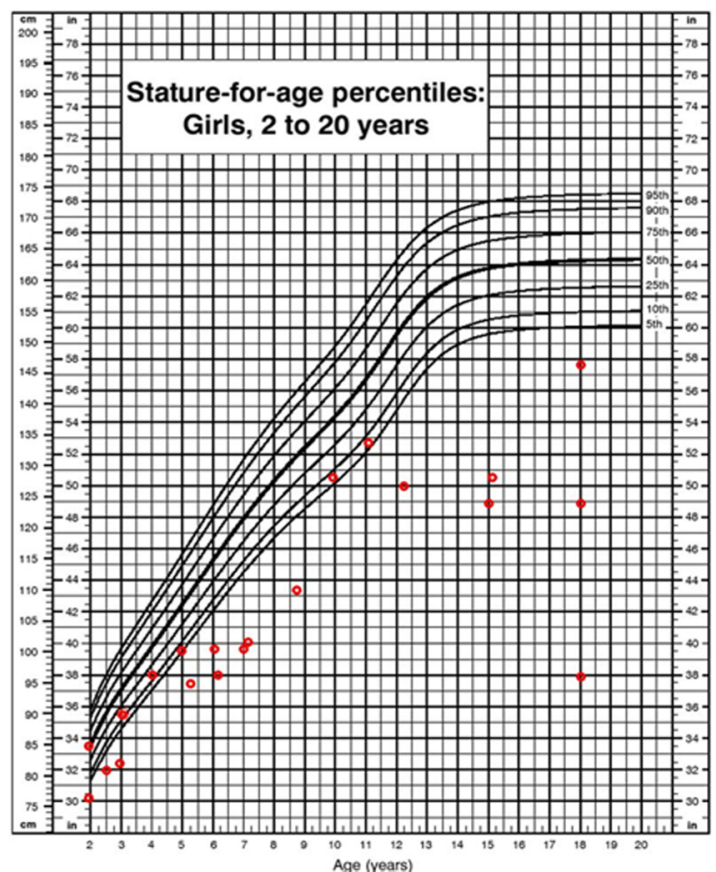

Figure 8 (A) Length for age in girls (0-36 months) affected with mucopolysaccharidosis VII (MPS VII). (B) Stature for age in girls (2-18 years) affected with MPS VII. Data are compared with normal growth charts from the CDC. 


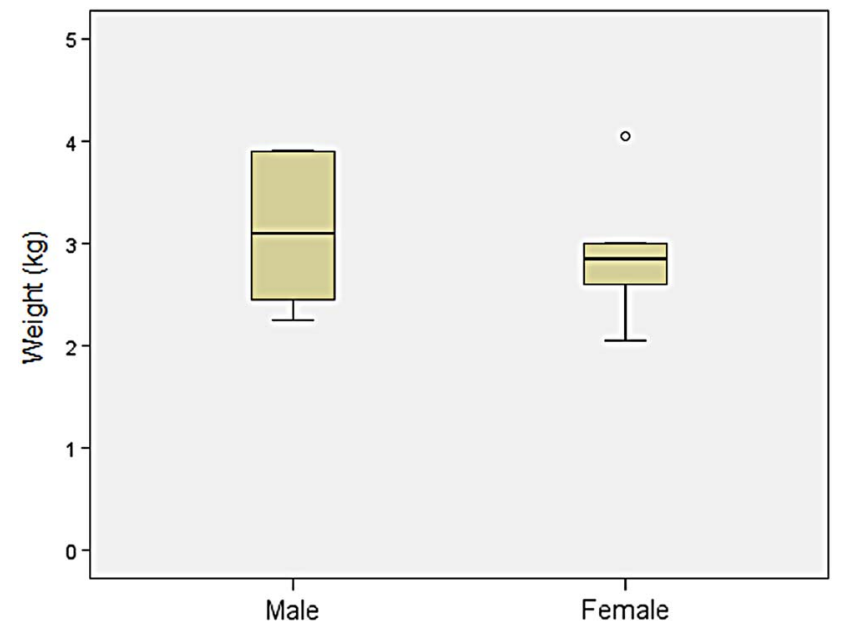

Figure 9 Comparison of birth weight of patients with mucopolysaccharidosis VII (MPS VII).

Progression of the disease beyond infancy was somewhat variable. Patients with mild or moderate early manifestations tended to deteriorate more slowly than patients with more severe manifestations. The clinical course of the disease at the last visit with the physician was reported as 'slowly worse' in $78 \%$ of the patients, 'stable' in 15\% and 'rapidly worse or other' in $7 \%$ of the patients $(n=27)$.

In agreement with the literature, repeated upper respiratory and pulmonary infections which required antibiotics were common in the first 2 years of life, after which there was a decrease in the frequency of infection with age. Mild to moderate mental retardation was common and usually required special education. Hearing impairment was common and likely contributed to delayed speech development. Skeletal deformities of the spine and chest wall were common and progressed gradually with age (figure 12). Most patients had hepatomegaly with limited excursion of the diaphragm which possibly contributed to respiratory insufficiency. Typically, hip dysplasia was associated with pain on walking which led to wheelchair dependency by age 10 years in some patients (figure 13). Prominent cardiac murmurs were common but serious valvular insufficiency was not.

Most patients underwent palliative, symptomatic-care treatments to improve their quality of life. These included surgeries, antibiotic treatment and physical therapy, among others. About $46 \%$ of the patients with the infantile or adolescent form of the disease had surgeries. The most common included: hernia repair, hip replacement and cervical fusion (figure 14). Seventeen per cent of the patients were able to perform daily activities by themselves, but more often, some assistance was required. Almost half of the patients with the infantile or adolescent form of the disease (46\%) were able to walk by themselves without assistance. However, most patients lost this ability with time due to hip dysplasia. Common causes of death included complications of hydrops fetalis with respiratory and renal failure, heart disease, decreased pulmonary function and/ or obstructive airway disease, complication of BMT and aspiration (figure 15).

\section{Treatment}

Bone marrow transplantation

In our survey we identified five patients that underwent BMT (table 4). Three survived.

BMT Patient 1, Spanish Caucasian girl, diagnosed at 1year 10 months of age. Onset of the disease was observed at birth due to the presence of talipes equinovarus and kyphosis. At 2 years of age BMT was performed, but failed with autologous reconstitution. At 4 years of age, BMT was performed once more with successful engraftment. At 4 years and 1 month of age, the patient had moderate clinical manifestations of the
A

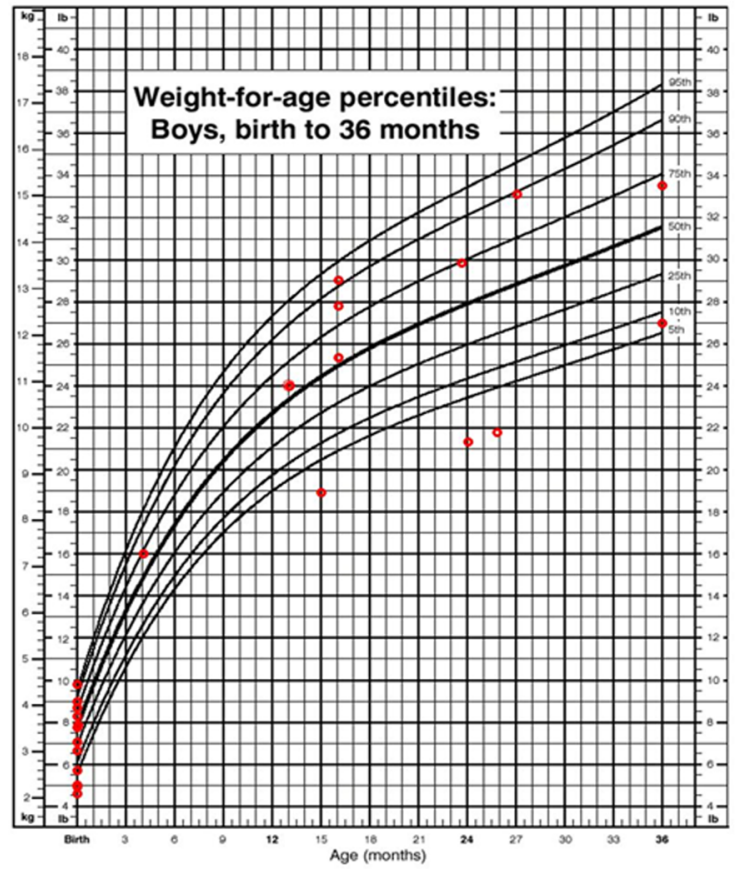

B

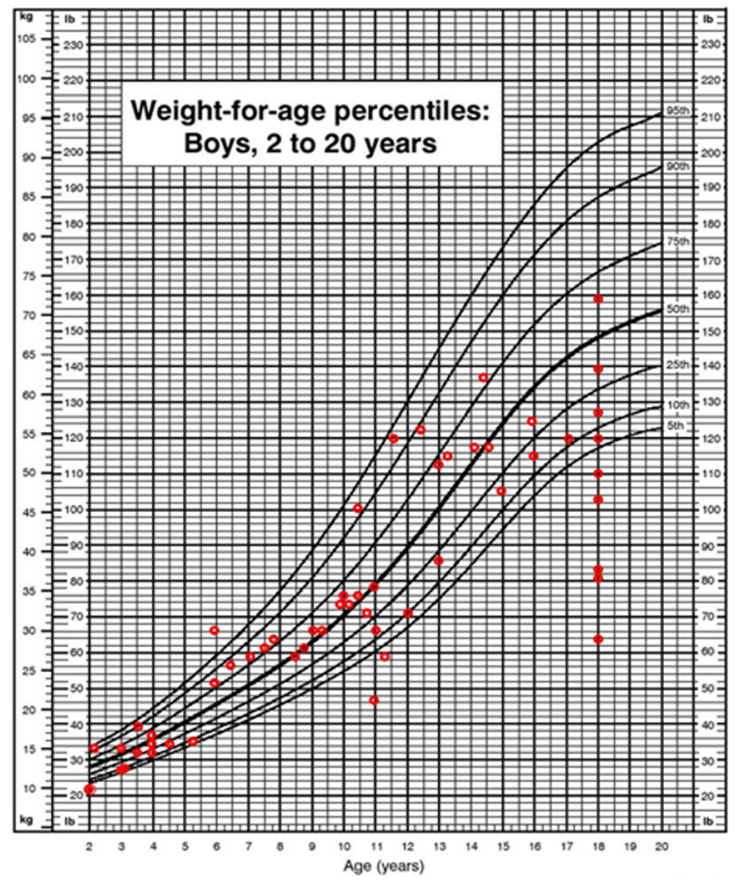

Figure 10 (A) Weight for age in boys (0-36 months) affected with mucopolysaccharidosis VII (MPS VII). (B) Weight for age in boys (2-18 years) affected with MPS VII. Data are compared with normal growth charts from the CDC. 
A

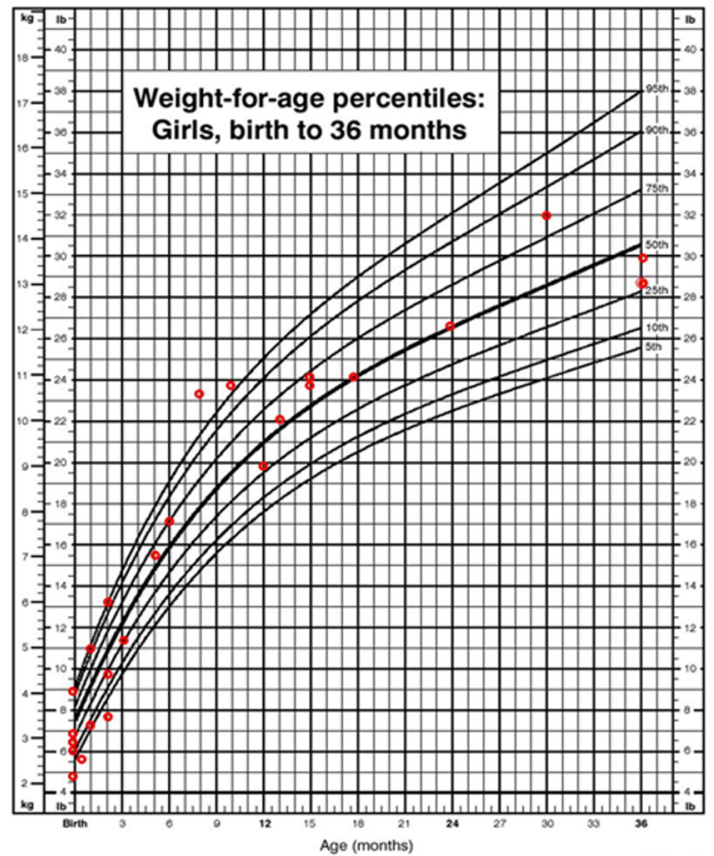

B

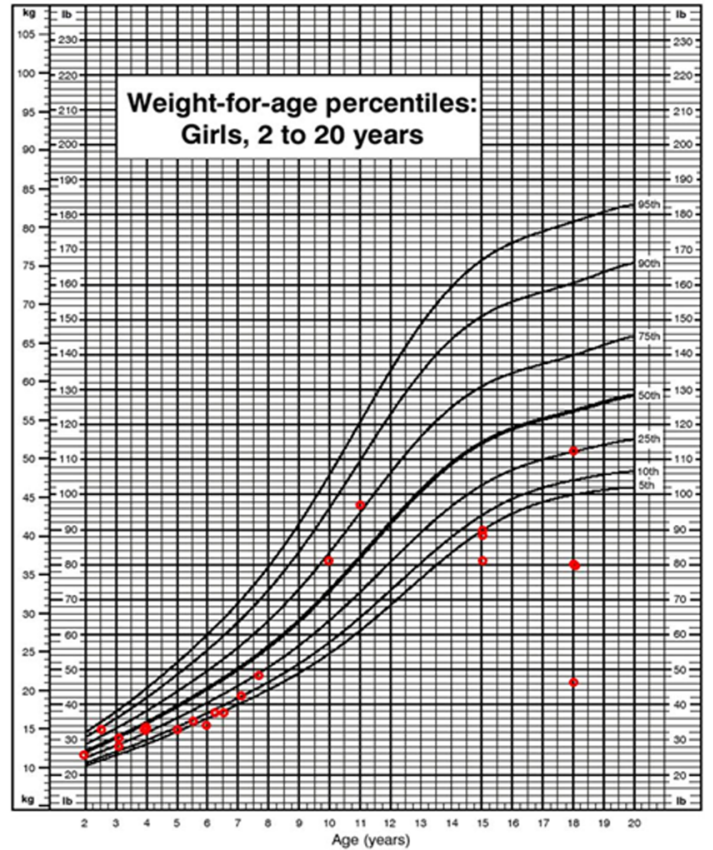

Figure 11 (A) Weight for age in girls (0-36 months) affected with mucopolysaccharidosis VII (MPS VII). (B) Weight for age in girls (2-18 years) affected with MPS VII. Data are compared with normal growth charts from the CDC.

disease with normal intelligence and slow progression of the disease. The patient has coarse facial features, short neck, heavy eyebrows, low set ears, exophthalmos and skeletal abnormalities including short stature, short trunk, pectus carinatum, joint contractures, genu valgum, kyphosis, scoliosis and talipes equinovarus. The result of the BMT on subsequent course is unknown.

BMT Patient 2, Brazilian black boy, diagnosed at 2 years of age. He had severe manifestations of the disease including mental retardation, coarse facial features, prominent forehead, prognathism, corneal clouding, visual impairment, recurrent respiratory infections, macroglossia, cardiac valve disease and decreased pulmonary function. He underwent BMT after 7 years of age, but subsequently died from complications of the procedure.

BMT Patient 3, Brazilian black boy, diagnosed at 4 months of age because of history of an older affected sibling. Initial symptoms included hepatomegaly and splenomegaly. He had severe manifestations of the disease with mental retardation. $\mathrm{He}$ had coarse facial features, prominent forehead, prognathism, corneal clouding, visual impairment, macroglossia, cardiac valve disease, short stature, short trunk, gibbus and deformity of the thorax, recurrent respiratory infections, decreased pulmonary function, hepatosplenomegaly, umbilical hernia, joint contractures and stiffness, restricted mobility, loss of joint range of motion, clawed hands, language impairment and hyperactivity. The patient died a few years after the procedure.

BMT Patient 4, Spanish Caucasian boy had prenatal hydrops fetalis at 22 weeks of gestation but MPS VII was not diagnosed until 26 months of age. Initial signs and symptoms included difficulty breathing, hepatosplenomegaly, inguinal hernia, coarse facial features, prominent forehead, mental retardation, developmental delay and short neck. He underwent BMT at 3 years of

Table 2 Mutations of patients with MPS VII in the survey $(n=6)^{*}$

\begin{tabular}{|c|c|c|c|c|c|c|c|c|}
\hline $\begin{array}{l}\text { Amino acid } \\
\text { changet }\end{array}$ & Exon & $\begin{array}{l}\text { Degree of } \\
\text { conservation } \neq\end{array}$ & $\begin{array}{l}\text { Amino acid } \\
\text { changet }\end{array}$ & Exon & $\begin{array}{l}\text { Degree of } \\
\text { conservation } \neq\end{array}$ & Population/ethnicity & $\begin{array}{l}\text { Presentation of the } \\
\text { disease }\end{array}$ & Phenotype \\
\hline p.D50Y & 1 & 2 & p.L565V & 11 & 4 & $\begin{array}{l}\text { American/ } \\
\text { African-American }\end{array}$ & Early onset (in utero) & Severe \\
\hline p.D89G & 2 & 4 & p.D362N & 7 & 1 & American/Caucasian & Early onset (in utero) & Normal§ \\
\hline p.V99M & 2 & 1 & p.W289X & 5 & 2 & American/Hispanic & Early onset (at birth) & $\begin{array}{l}\text { Severe with severe } \\
\text { MR }\end{array}$ \\
\hline p.L176F & 3 & 1 & p.L176F & 3 & 1 & $\begin{array}{l}\text { Mexican-American/ } \\
\text { Hispanic }\end{array}$ & Early onset (at birth) & $\begin{array}{l}\text { Severe with } \\
\text { moderate MR }\end{array}$ \\
\hline p.R382C & 7 & 1 & p.R382C & 7 & 1 & Japanese/Asian & $\begin{array}{l}\text { Early onset (1- } \\
3 \text { years) }\end{array}$ & Mild with MR \\
\hline p.P408S & 7 & 2 & p.P415L & 7 & 5 & $\begin{array}{l}\text { Mexican-American/ } \\
\text { Hispanic }\end{array}$ & Early onset (at birth) & $\begin{array}{l}\text { Moderate with } \\
\text { severe MR }\end{array}$ \\
\hline
\end{tabular}

${ }^{*}$ More extensive data on mutations in MPS VII is available in references. ${ }^{28-32}$

†The methionine encoded by the translation initiation site (start codon) is numbered as residue 1 (http://www.hgvs.org/mutnomen)

¥1. Conserved among all species; 2 . Vertebrate specific; 3. Mammal specific; 4. Domestic species specific; 5 .Non-conserved.

$\S B M T$ Patient 5.

BMT, bone marrow transplantation; MPS VII, mucopolysaccharidosis VII; MR, mental retardation. 
Table 3 Patients with MPS VII from the survey with history of neonatal non-immune hydrops fetalis (NIHF)

\begin{tabular}{|c|c|c|c|c|c|c|c|c|c|}
\hline Patient & $\begin{array}{l}\text { Maternal } \\
\text { parity }\end{array}$ & Gender & Race, ethnicity & $\begin{array}{l}\text { Country of } \\
\text { birth }\end{array}$ & $\begin{array}{l}\text { Prenatal } \\
\text { diagnosis of } \\
\text { hydrops }\end{array}$ & $\begin{array}{l}\text { Weeks gestation } \\
\text { at delivery or } \\
\text { termination }\end{array}$ & Patient age at publication & Congenital abnormalities or most current symptoms & $\begin{array}{l}\text { Recovered } \\
\text { from } \\
\text { hydrops? }\end{array}$ \\
\hline 1 & G4, P2 & Female & Hispanic & Argentina & Unknown & Unknown & Deceased—prenatal onset & $\begin{array}{l}\text { Ascites, affected kidneys, haematised facies, brain ventriculomegaly, } \\
\text { hepatosplenomegaly, respiratory failure }\end{array}$ & Unknown \\
\hline 2 & G5, P2 & Male & Hispanic & Argentina & 33 weeks & Unknown & Deceased—prenatal onset & Ascites at 33 weeks, renal damage & Unknown \\
\hline 3 & G6, P2 & Female & Hispanic & Argentina & 35 weeks & Unknown & Deceased—prenatal onset & $\begin{array}{l}\text { Ascites at } 35 \text { weeks, hepatosplenomegaly and vacuolated macrophages, } \\
\text { hepatocytes and renal tubules }\end{array}$ & Unknown \\
\hline 4 & Unknown & Male & Unknown & Germany & Unknown & Unknown & Deceased—prenatal onset & Umbilical hernia, macrocephaly, cardiac valve pathology & Unknown \\
\hline 5 & Unknown & Unknown & Unknown & Germany & Unknown & Unknown & Deceased—prenatal onset & & Unknown \\
\hline 6 & Unknown & Unknown & Unknown & Germany & Unknown & Unknown & Deceased_prenatal onset & & Unknown \\
\hline 7 & Unknown & Unknown & Unknown & Germany & Unknown & Unknown & Deceased—prenatal onset & & Unknown \\
\hline 8 & Unknown & Unknown & Unknown & Germany & Unknown & Unknown & Deceased_prenatal onset & & Unknown \\
\hline 9 & Unknown & Unknown & Unknown & Germany & Unknown & Unknown & Deceased—prenatal onset & & Unknown \\
\hline 10 & Unknown & Unknown & Unknown & Germany & Unknown & Unknown & Deceased_prenatal onset & & Unknown \\
\hline 11 & Unknown & Female & Unknown & Germany & Unknown & Unknown & Unknown & $\begin{array}{l}\text { Inguinal hernia, coarse facial features, mental retardation, dysostosis } \\
\text { multiplex, hepatosplenomegaly, cardiac valve pathology, hearing loss, } \\
\text { recurrent otitis media }\end{array}$ & Yes \\
\hline 12 & G1, P1 & Male & Hispanic & USA & Unknown & 38 weeks & Deceased at 11 years of age & $\begin{array}{l}\text { Coarse facies, macrocephaly, short neck, coarse hair, corneal clouding, } \\
\text { abnormal dentition, macroglossia, inguinal hernia, recurrent otitis } \\
\text { media, dysostosis multiplex, cardiomyopathy, obstructive airway disease, } \\
\text { chronic bronchitis, narrowed trachea, decreased pulmonary function, } \\
\text { hepatosplenomegaly, joint stiffness and contractures, mental } \\
\text { retardation, limited vocabulary, progressive neurological deterioration }\end{array}$ & Yes \\
\hline 13 & $\mathrm{G} 2, \mathrm{P} 2$ & Male & Caucasian & USA & Unknown & Unknown & 5 months & $\begin{array}{l}\text { Macrocephaly, coarse facial features, short neck, coarse hair, corneal } \\
\text { clouding, visual impairment, recurrent otitis media and hearing loss, } \\
\text { chronic rhinorrhoea and snoring, recurrent respiratory infections, dental } \\
\text { problems, dysostosis multiplex, hepatosplenomegaly, inguinal hernia, } \\
\text { mental retardation }\end{array}$ & Yes \\
\hline $14^{*}$ & G1 & Male & Caucasian & Turkey & Unknown & Unknown & Deceased at 2 years of age & $\begin{array}{l}\text { Micrognathia, hepatosplenomegaly, oedema in hands, feet and scrotum, } \\
\text { arteriosus and septum defect, hydrocele in scrotum, hearing loss, } \\
\text { hydrocephaly, cervical /spinal canal stenotic; at } 2 \text { years of age, } \\
\text { macrocephaly, coarse facial features, short neck, corneal clouding, } \\
\text { hearing loss, recurrent otitis media, recurrent respiratory infections, } \\
\text { macroglossia, inguinal hernia, dysostosis multiplex, joint stiffness, } \\
\text { restricted mobility, hydrocephalus, mental retardation, progressive } \\
\text { neurological deterioration and limited vocabulary }\end{array}$ & Yes \\
\hline $15^{*}$ & Unknown & Female & Hispanic & Brazil & Unknown & Unknown & 2 years 10 months & Oedema at birth, hepatosplenomegaly & Yes \\
\hline 16 & G1, P1 & Female & Hispanic & Brazil & Unknown & Unknown & 7 years 2 months & $\begin{array}{l}\text { Hepatosplenomegaly, coarse facial features, macrocephaly, enlarged } \\
\text { kidney, haemangioma in leg, epicanthic fold, wide nose, macrostomia; } \\
\text { at } 7 \text { years } 2 \text { months, mild breast bone deformation, thick mitral valve, } \\
\text { history of asthma, cannot talk }\end{array}$ & Yes \\
\hline
\end{tabular}




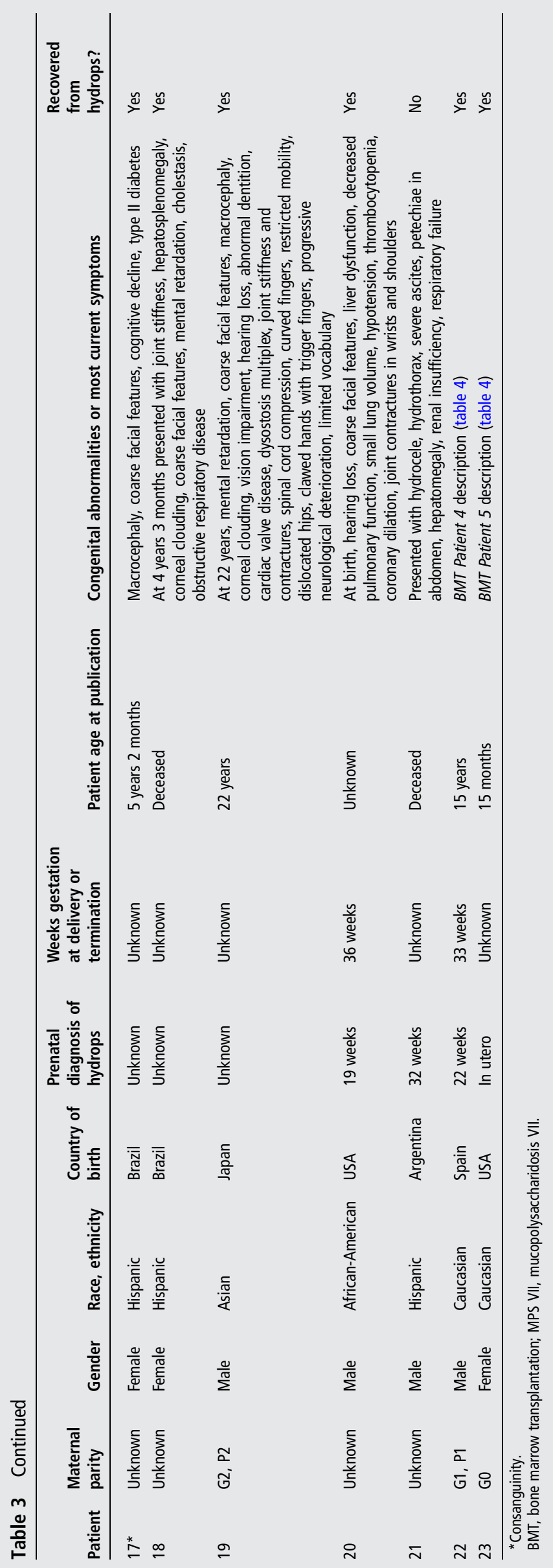

age. At 15 years of age, he showed a moderate clinical phenotype suggesting the disease may have stabilised somewhat after BMT. However, at the last exam he showed coarse facial features, short neck, corneal clouding, visual impairment, photosensitivity and dry eyes. After BMT, he still had otitis media, swallowing difficulties and recurrent respiratory infections. $\mathrm{He}$ also had abnormal dentition with caries, thin enamel, gingival hypertrophy and macroglossia. Skeletal abnormalities included short stature, short trunk, gibbus, joint contractures, odontoid hypoplasia, scoliosis, kyphosis, genu valgum, curved fingers, clawed hands, restrictive mobility, loss of joint range of motion, decreased wrist range of motion and thorax deformities. This patient also had restrictive and obstructive airway disease, asthma, chronic bronchitis and decreased pulmonary function. The patient was hydrocephalic with language impairment. $\mathrm{He}$ also had atopic dermatitis.

BMT Patient 5, American Caucasian girl, had hydrops fetalis, fetal cardiac distress, tachycardia. MPS VII was diagnosed at 2 weeks of age and she underwent BMT at 7 months of age. At age 15 months she had no clinical manifestations. Hepatomegaly had disappeared. Intelligence appeared normal and she achieved normal developmental milestones, including walking at 1 year of age. The patient exhibits a prominent forehead, and some cardiomyopathy with mild atrial enlargement.

\section{Enzyme replacement therapy}

Enzyme replacement therapy (ERT) Patient 1, Asian-American boy, had hydrops fetalis and splenomegaly. He was diagnosed at 18 months of age when he presented with severe cord compression for which he underwent cervical fusion. ${ }^{37}$ The patient eventually learned how to walk and attended school but lost the ability to walk as the disease progressed. He suffered from upper airway obstruction, progressive heart valve disease and hepatosplenomegaly. The main complications involved his pulmonary status. He was hospitalised several times for respiratory failure and elevated end-tidal carbon dioxide levels of $80 \mathrm{~mm} \mathrm{Hg}$ or more. ${ }^{38}$

Due to the patient's pulmonary failure despite usage of maximum resources to improve his pulmonary function, an emergency request for compassionate use of investigational recombinant human GUS (rhGUS) therapy was made and granted by the US Food and Drug Administration. The enzyme was provided by Ultragenyx Pharmaceutical.

The patient was treated with intravenous infusions of $2 \mathrm{mg} / \mathrm{kg}$ of rhGUS every other week. After 24 weeks of treatment, no serious adverse effects were noted. The levels of GAGs in the urine decreased approximately $60 \%$ from the baseline, spleen and liver size declined, and pulmonary function improved as evidenced by increased tolerance for off-ventilator challenges. Quality of life was improved and he regained the ability to attend school and to eat some food orally. This patient's experimental treatment with ERT is still ongoing. A report summarising the clinical course for ERT Patient 1 to date was recently published. ${ }^{38}$ Additional formal clinical trials of ERT on patients with MPS VII are underway in the USA and Europe.

\section{DISCUSSION}

Since the description of the first patient with MPS VII by Sly et al in $1973^{1}$ several authors have reported on the heterogeneous nature of the disease. ${ }^{4-9}{ }^{39-44}$ Marked variation in phenotypical expression has been seen in the 90 patients with MPS VII reported in the literature and confirmed by the information obtained in this study. Including the patients from this study we have information on a total of 143 patients with MPS VII 
Figure 12 Spine films in a patient with mucopolysaccharidosis VII (MPS VII) demonstrate findings common to all forms of MPS at age 7 years (A and $B)$ and age 8 years (C and D).

Anteroposterior views ( $A$ and $C$ ) reveal mild scoliosis (arrow) and broad ribs. The lateral films ( $B$ and $D$ ) demonstrate irregular anterior vertebral body growth, particularly at the L2 level (arrow).

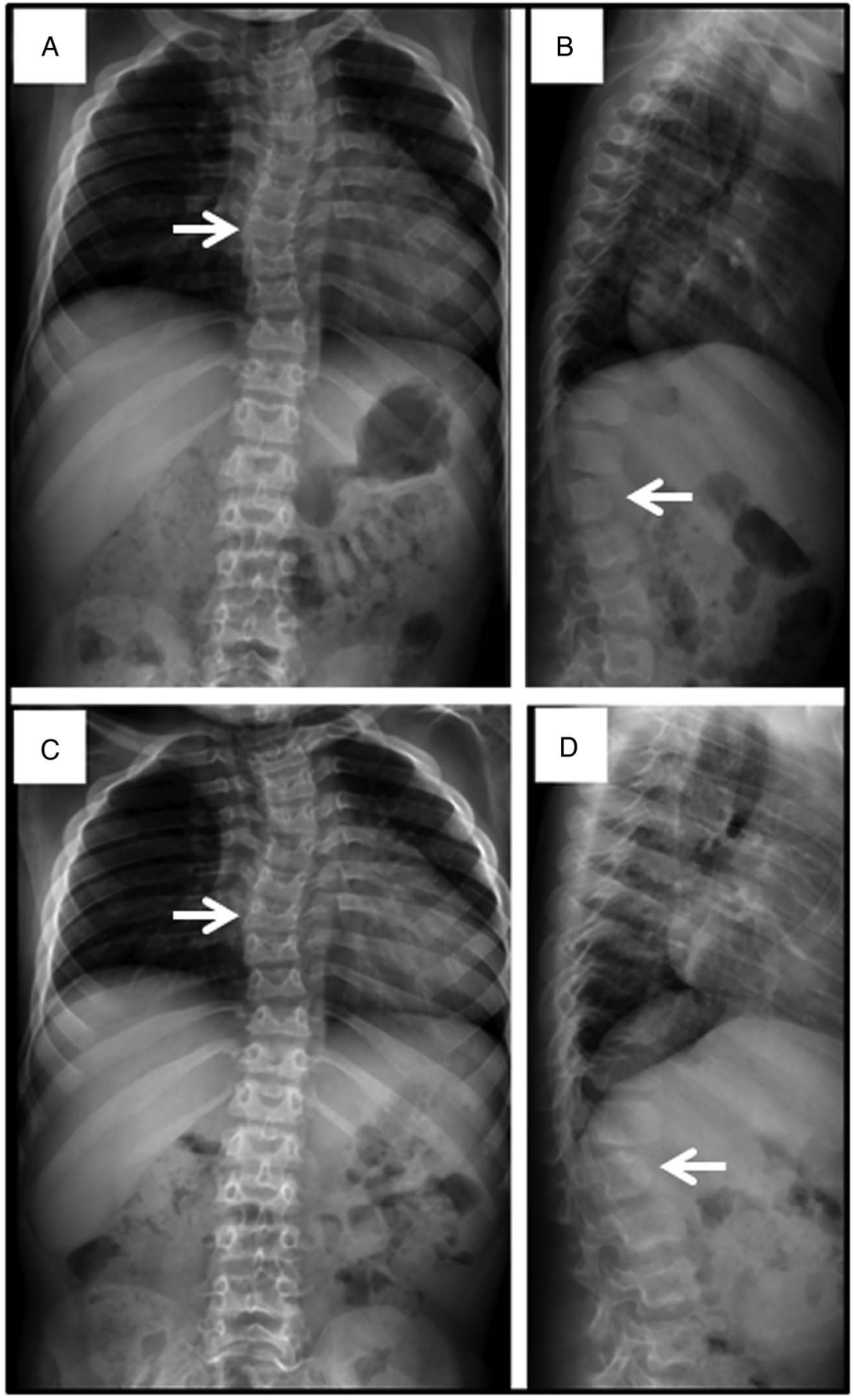

diagnosed in 30 countries. Overall, patients with mild or moderate manifestations have coarse facial features, corneal clouding, frequent upper respiratory infections but mild skeletal abnormalities. Patients with more severe phenotypes exhibit short stature and greater skeletal dysplasia, macrocephaly, recurrent ear infections, gingival hypertrophy, hepatosplenomegaly, hernias and cognitive impairment. ${ }^{4-7} 939$

The most severe form of MPS VII disease is characterised by the presence of NIHF. NIHF is a condition in which there is excessive fluid accumulation within fetal extravascular compartments and body cavities, that is not caused by red cell alloimmunisation. ${ }^{45}$ NIHF has been reported multiple times in fetuses with MPS VII showing marked ascites, oedema of the limbs, hepatosplenomegaly, delayed brain development, mild decrease of ventricular function, liver disease, severe lung hypoplasia, dilated heart and, at autopsy, presence of foamy macrophages in the brain. ${ }^{21}{ }^{46-55}$ One of the suggested mechanisms to explain hydrops in some MPS VII cases is the obstructive effects of hepatic sinusoidal infiltration leading to generalised oedema. ${ }^{21}$ In our survey, 23 patients (41\%) had a history of hydrops (neonatal NIHF or infantile). In addition, one patient with MPS VII was reported to have isolated neonatal ascites without generalised oedema. ${ }^{56}$ These results are similar to figures in the literature in which 35 out of 90 cases $(38.8 \%)$ with MPS VII had a history of NIHF. Thus, it is important to include MPS VII in the differential diagnosis of NIHF.

Cardiovascular involvement has been reported in many patients with MPS VII. Findings included left ventricular hypertrophy, aortic insufficiency, mitral regurgitation, congestive cardiac failure, aortic stenosis, and thickened aortic and mitral 
Figure 13 Progressive hip dysplasia is seen in this patient with mucopolysaccharidosis VII (MPS VII). At age 7 years $(A)$, the right hip shows subluxation with poor coverage, while the left hip is already dislocated and sits in a pseudoacetabulum (arrow). By age 8 years $(C)$, an acetabular shelf procedure has been performed and by age 10 years $(\mathrm{E})$, has not prevented further subluxation and femoral head erosion (arrow).

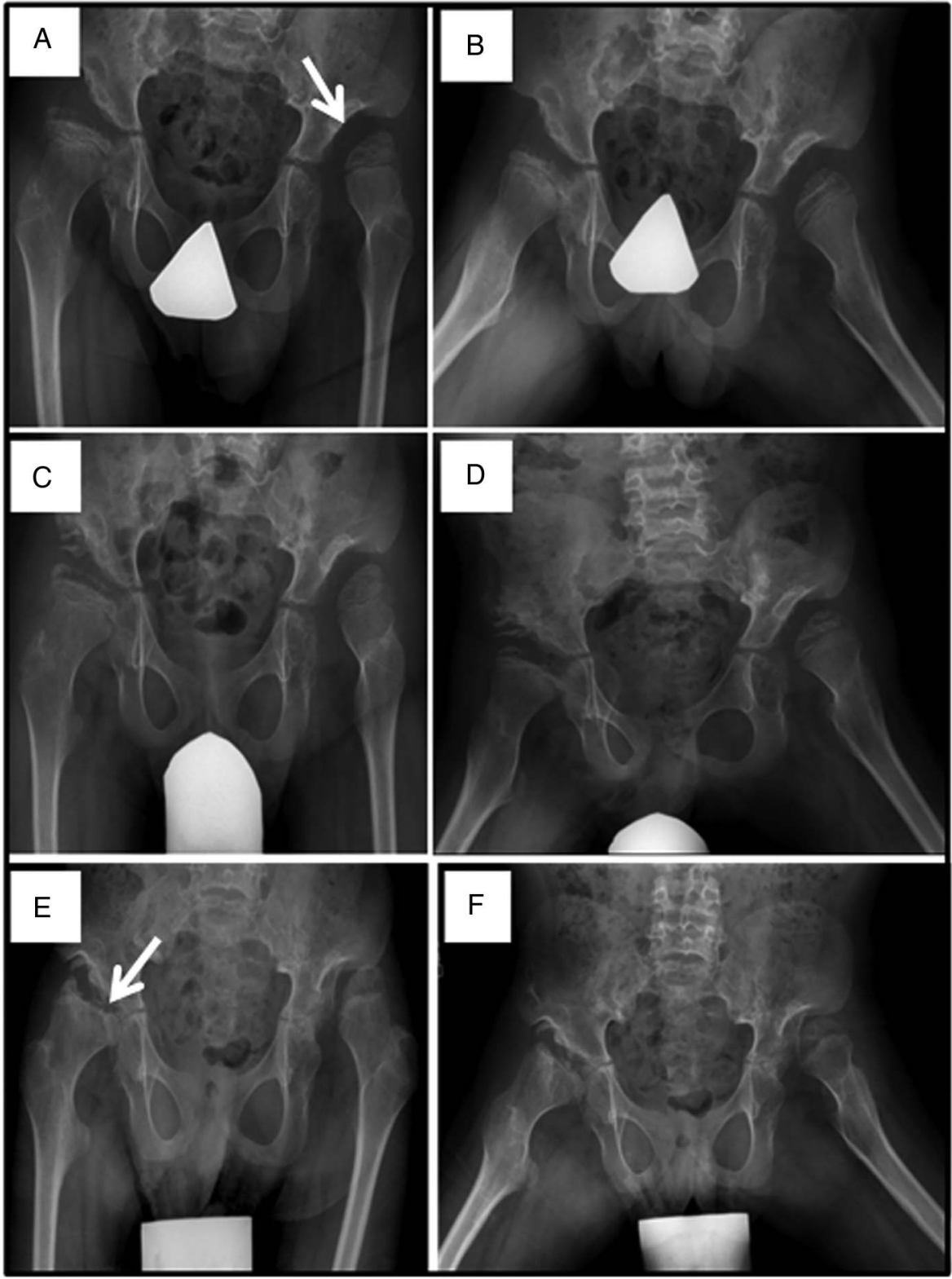

valves. $^{9} 30{ }^{57-61}$ In this study over $50 \%$ of patients with MPS VII had cardiac valve disease. Indeed, the postmortem analysis of the first patient reported with MPS VII, who died suddenly at age 20 years, found extensive cardiovascular lesions including arterial stenosis and marked fibrous thickening of the atrioventricular and aortic valves. ${ }^{62}$ Similar cardiac findings at autopsy of another patient aged 28 years were recently reported. ${ }^{63}$

In our study we observed decreased pulmonary function (both restrictive and obstructive) in $71 \%$ of the patients. Thoracic deformities including pectus carinatum or excavatum contribute to restrictive airway disease leading to chronic hypoventilation with low forced vital capacity. ${ }^{61}{ }^{64}$ There are reports of individual patients with severe pulmonary disease including bronchopulmonary dysplasia with fibrosis, recurrent pneumothoraces, interstitial lung disease and prolonged oxygen dependency.

In this study $90 \%$ of patients with MPS VII had skeletal dysplasia. Bone abnormalities in these patients and those previously reported included vertebral beaking, platyspondyly, hypoplastic odontoid process with atlantoaxial instability, kyphosis, scoliosis, pectus carinatum, bilateral dysplasia of femoral head and acetabulum, hip subluxation, widening of iliac wings, genu valgum, femoral capital epiphyses flattened and irregular, acetabular roofs irregular and fragmented, pseudoarthrosis, and interestingly, early bone maturation in utero. $40445764-67$

Skeletal changes often limit mobility. In this study, $57 \%$ of the patients $(n=16)$ could walk without assistance. Twenty-one per cent of patients used a wheelchair, $11 \%$ used a walker or crutches and $11 \%$ could not mobilise at all. Though not frequently commented on in this study, odontoid hypoplasia has been reported in many patients. ${ }^{1838}$ Its detection is important because atlantoaxial instability of the neck can pose a threat of cervical dislocation from trauma or intubation for anaesthesia. The patient shown in figure 1 died at age 12 years undergoing dental anaesthesia.

Central nervous system findings are prominent in patients with MPS VII. In our survey $28 \%$ of patients had cordcompression. Associated signs include hyper-reflexia and clonus. In addition, 94\% had delay in their linguistic domain and $86 \%$ had mental retardation. Previous reports have also noted the presence of mental retardation and delay in cognitive, linguistic 


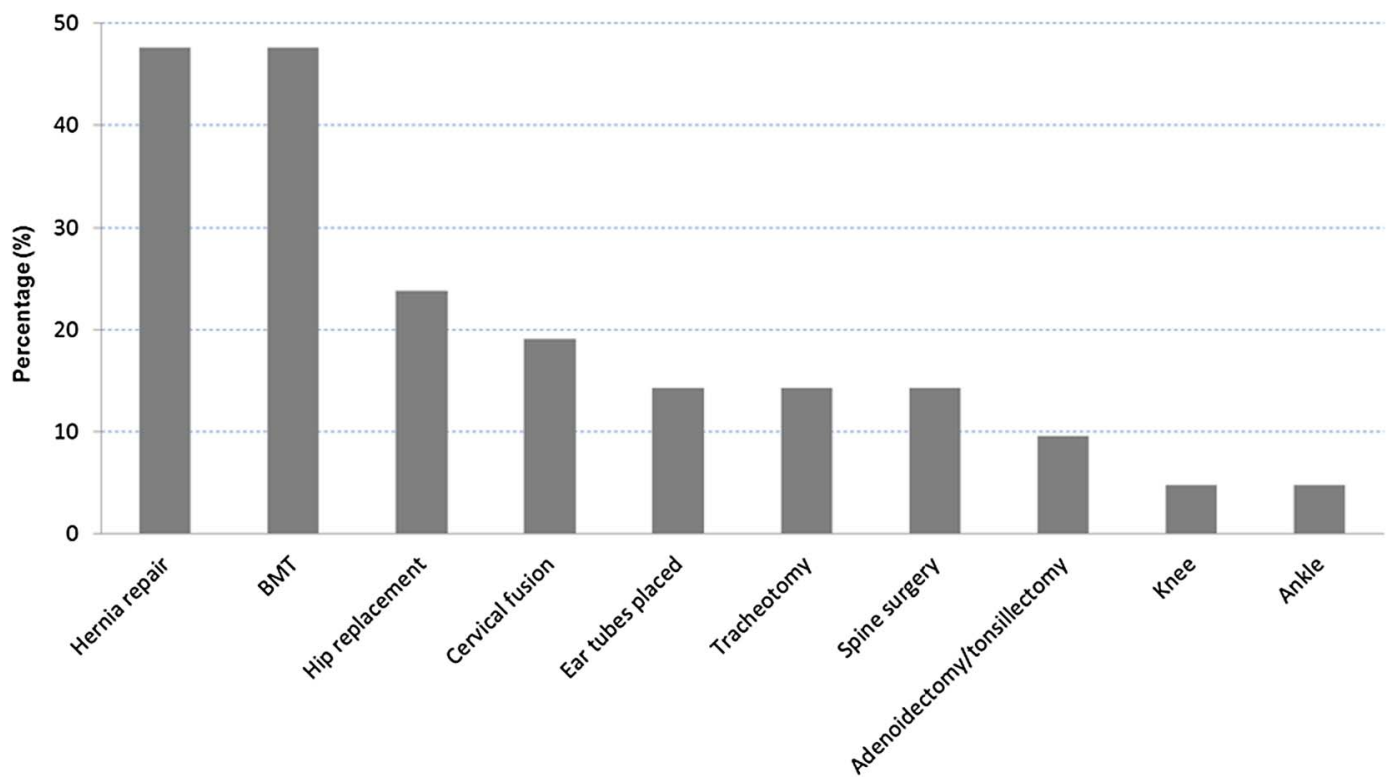

Figure 14 Distribution of surgical operations performed on patients with mucopolysaccharidosis VII (MPS VII) ( $\mathrm{n}=21,45.6 \%$ of total number of patients).

and social domains in patients with MPS VII. ${ }^{68} \mathrm{~A}$ postmortem analysis in a 20 -year-old adult patient showed neuronal loss in substantia nigra and anterior columns of the spinal cord. ${ }^{62}$

Hearing impairment is reported to be common in patients with MPS VII. ${ }^{68}$ In this survey we found that $41 \%$ of patients with MPS VII had sensorineural hearing loss. Chronic otitis media and upper respiratory tract infections have been reported to be common. ${ }^{68}$ In this study $52 \%$ of the patients had ear infections and 69\% had respiratory infections.

Other findings in occasional patients with MPS VII include kidney enlargement, renal insufficiency, hemiparesis, retinitis pigmentosa and some gastrointestinal (GI) disturbances including diarrhoea, dysphagia, reflux and colitis. Four patients had neonatal cholestasis (ref. 58, Bérubé et al; this study).

Phenotypical characteristics of patients with MPS VII resemble those of MPS I and MPS II (short stature, skeletal dysplasia, hepatosplenomegaly, hernias, cardiac involvement, decreased pulmonary function and cognitive impairment). In MPS VII, however, one unique and distinguishing clinical feature is the unexpectedly high proportion of patients (41\%) that had a history of NIHF. Despite the prenatal onset of clinical disease in these patients, 13 out of 23 survived infancy with a mild to intermediate course into their late teens. Thus presence of NIHF does not, by itself, predict the eventual severity of the clinical course, if the patient survives infancy.

Causes of death in patients with MPS VII reported in the literature and in this study included cardiac arrhythmia, kidney failure, cardiac arrest, and in one case, pulmonary aspiration. $^{26} 4462$

For many years palliative therapies were the only resource for patients with MPS. These include surgeries, oxygen supplementation, antibiotics, non-steroidal anti-inflammatory drugs and physical therapy. Although specific treatments for MPS VII have lagged behind therapies for other LSDs because of its rarity and clinical variability, experimental approaches to treatment using animal models for this disorder have been very informative and have produced promising results.

The MPS VII mouse was shown to be greatly improved by ERT. The treatment effect was greatest if given early in life including prevention of some of learning, memory and hearing deficits. ${ }^{69}$ Vogler et $a l^{70}$ reported that high dose of enzyme (weekly injection of $4 \mathrm{mg} / \mathrm{kg}$ for 13 weeks) could cross the blood-brain barrier and improve glia and neocortical neurons. In addition, reports showed that chemically modified GUS enzyme which had longer circulating half-life improved clearance of GAG accumulation in several tissues including brain ${ }^{71}$

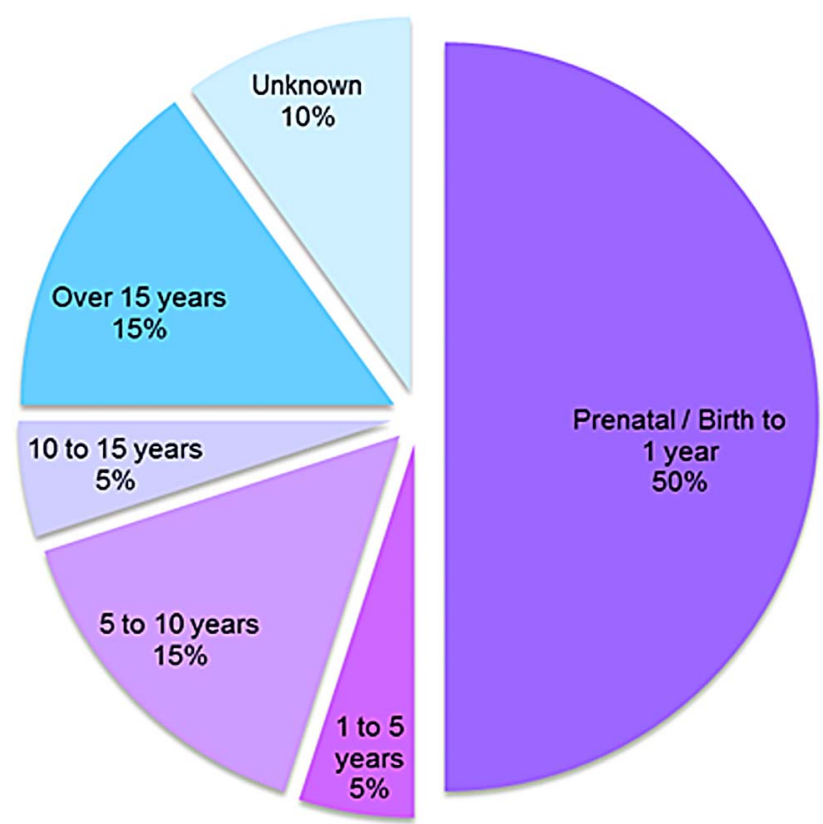

Figure 15 Distribution of causes of death by age. Causes included: Prenatal to 1 year, $(50 \%)$ complications of hydrops fetalis, respiratory failure and renal failure; ages $1-5$ years $(5 \%)$, obstructive airway disease; ages $5-10$ years (15\%), heart disease, complications of bone marrow transplantation (BMT) and pulmonary failure; ages 10-15 (5\%), decreased pulmonary function; and over 15 years of age, heart disease, pulmonary failure and/or obstructive airway disease, and aspiration/heart attack. 
Table 4 Patients from the survey that underwent bone marrow transplantation (BMT)

\begin{tabular}{lllll}
\hline Patient & Gender & Country & Age of BMT & Status \\
\hline 1 & F & Spain & 2 years and 4 years & A \\
2 & M & Brazil & - & D \\
3 & M & Brazil & - & D \\
4 & M & Spain & 3 years & A \\
5 & F & USA & 7 months & A \\
\hline A, alive; D, deceased. & & &
\end{tabular}

and skeletal tissue. ${ }^{72}$ BMT also altered the course of the disease and combination of ERT and BMT gave better results than either monotherapy. ${ }^{73}$ Gene therapy (GT) has been shown to be effective by several investigators. Davidson's group ${ }^{74}$ showed that GT directed to brain could reverse established cognitive impairment. Potentially promising results were also reported in an MPS VII dog using retroviral GT. ${ }^{75}$ These preclinical experiments in many laboratories provided optimism for the potential to develop ERT for patients with MPS VII. rhGUS is under clinical development as a potential ERT.

The first opportunity for clinical application was provided by a 12-year-old patient whose seriously deteriorating condition led to granting an emergency Investigational New Drug (IND) Application for ERT on a compassionate use basis. Results of this patient's response to therapy over the first 24 weeks were recently reported. ${ }^{38}$ Further studies documenting response over the 1 st year were also recently presented. ${ }^{76}$ More recently a phase I/II clinical study was undertaken in UK involving 3 patients and a phase III study involving 12 patients in the USA is now underway.

Another approach to a non-palliative treatment is BMT. In BMT the enzyme that is missing is supplied endogenously through synthesis by the transplanted stem cells. ${ }^{77}$ Birkenmeier et $a l^{78}$ showed that BMT in adult GUS-deficient mice ${ }^{79}$ increased life span and produced clearance of GAGs in liver, spleen and partial correction in kidneys with minimal correction in the central nervous system and the skeleton. ${ }^{78}$ A Japanese patient underwent successful BMT at 12 years of age and after 2 years the levels of GUS were stable, with improvement of motor functions (walking, riding and taking bath alone), recurrent infections and snoring; however there was no reversal of the neurological damage. ${ }^{80}$ A Mexican female patient with MPS VII with genotype P408S/P415L underwent BMT at 11 years of age and was reported to be doing well 2 years after the transplantation. ${ }^{30}$ In the current study, five patients underwent BMT. Two of them died but the three survivors had some clinical benefit. The limited results suggest that BMT can slow or even prevent further neurological complications, but has little to no effect on the skeletal disease unless it is performed in neonates. ${ }^{81} 82$ The main limitations of BMT in MPS have been the difficulty in finding appropriate donors and the high morbidity and mortality after BMT. Availability of donors improved when using umbilical cord blood as a source of stem cell became accepted. Haematopoietic stem cells from umbilical cord human leukocyte antigen (HLA) system matched have proved to be safe and effective, are much more readily available than bone marrow, and require a less strict HLA match. ${ }^{77}$

Although MPS VII was the first MPS that had its enzyme characterised catalytically and the first to provide an ideal mouse model, it took over 40 years from the time of its discovery until the possibility of clinical trials could be realised. Along the way, studies of cells from the first identified patient had an important impact on the field. They led to the elucidation of the mannose- 6 phosphate targeting system on which most of the ERTs are dependent. Studies of the clearance and uptake of the non-phosphorylated form of GUS led to elucidation of the mannose targeting system which formed the basis for ERT in Gaucher disease. Lessons from the mouse model of MPS VII have been similarly influential. The great leap from mouse to man is anxiously awaited.

\section{Author affiliations}

${ }^{1}$ Department of Pediatrics, School of Medicine, Saint Louis University, St. Louis, Missouri, USA

${ }^{2}$ Edward A. Doisy Department of Biochemistry and Molecular Biology, School of Medicine, Saint Louis University, St. Louis, Missouri, USA

${ }^{3}$ Metabolic and Clinical Genetics, Kuala Lumpur Hospital, Kuala Lumpur, Malaysia

${ }^{4}$ Oregon Health \& Science University, Portland, Oregon, USA

${ }^{5}$ Marshfield Clinic Research Foundation, Marshfield, Wisconsin, USA

${ }^{6}$ Current Affiliation: University of Wisconsin, Madison, Wisconsin, USA

${ }^{7}$ Department of Molecular and Human Genetics, Baylor College of Medicine,

Houston, Texas, USA

${ }^{8}$ Consultorio de Enfermedades Metabólicas, Hospital de Niños R. Gutiérrez, Buenos Aires, Argentina

${ }^{9}$ University of Connecticut Health Center, Farmington, Connecticut, USA

${ }^{10}$ Fundació, Hospital Sant Joan De Déu, Centre for Biomedical Research on Rare Diseases, Instituto de Salud Carlos III, Barcelona, Spain

${ }^{11}$ Hospital Universitario Virgen del Rocío and Universidad de Sevilla, Sevilla, Spain

${ }^{12}$ Faculty of Medicine, Ege University, Izmir, Turkey

${ }^{13}$ Division of Molecular and Human Genetics, Nationwide Children's Hospital, Columbus, Ohio, USA

${ }^{14}$ Washington University School of Medicine, St Louis, Missouri, USA

${ }^{15}$ Division of Metabolic Disorders, CHOC, Children's Hospital Orange County,

Orange, California, USA

${ }^{16}$ Department of Pediatrics, University of California-Irvine School of Medicine,

Orange, California, USA

${ }^{17}$ Medical Genetics Service/HCPA \& Department of Genetics/UFRGS, Porto Alegre, Brazil

${ }^{18}$ Hospital Universitari Vall d'Hebron, Barcelona, Spain

${ }^{19}$ New York University Medical Center, New York, New York, USA

${ }^{20}$ University of Michigan Health Systems, Ann Arbor, Michigan, USA

${ }^{21}$ Minnesota Neonatal Physicians P.A., Children's Hospitals and Clinics of Minnesota,

Minneapolis, Minnesota, USA

${ }^{22}$ Gazi University Faculty of Medicine, Ankara, Turkey

${ }^{23}$ Osaka City University Graduate School of Medicine, Osaka, Japan

${ }^{24}$ Childrens Hospital, Johannes Gutenberg University Medical Center, Mainz, Germany

${ }^{25}$ Genetics Institute, Cedars Sinai Medical Center, Los Angeles, California, USA

${ }^{26}$ Discipline of Paediatrics and Child Health, The Children's Hospital at Westmead,

Sydney, Australia

${ }^{27}$ Hospital Infantil Sabará, Sao Paulo and Sao Paulo University, Sao Paulo, Brazil

${ }^{28}$ Seattle children's Hospital, Seattle, Washington, USA

${ }^{29}$ Department of Pediatrics, Centre Hospitalier Universitaire Sainte-Justine, Université de Montréal, Montreal, Canada

${ }^{30}$ Department of Human and Medical Genetics, Vilnius University, Vilnius, Lithuania

${ }^{31}$ School of Medicine, Saint Louis University, St. Louis, Missouri, USA

Acknowledgements The authors thank Anita Misra-Press for providing medical writing support.

Contributors AMM designed the research study. AMM performed the interviews. $\mathrm{NL}-\mathrm{H}, \mathrm{RDS}, \mathrm{BHG}, \mathrm{MS}, \mathrm{RG}, \mathrm{MP}, \mathrm{AG}-\mathrm{M}, \mathrm{MC}, \mathrm{DB}, \mathrm{MSS}, \mathrm{RW}, \mathrm{RGi}, \mathrm{AM}, \mathrm{GP}, \mathrm{AKK}, \mathrm{FE}$, $A T, L A, M B, R E F, K B, J F, K K W, G A M, L C$ and WSS contributed clinical information. $A M M$ and $M H$ analysed the data. AMM and WSS wrote the manuscript with inputs from all the coauthors.

Funding This work was supported in part by Ultragenyx Pharmaceutical grant number 16232.

Competing interests AMM has received funds from Ultragenyx Pharmaceutical to conduct this survey. AG-M and RW are principal investigators in clinical trials in patients with MPS VII supported by Ultragenyx Pharmaceutical. KW has received funds from BioMarin Pharmaceuticals. AMM has received funds from Actelion Pharmaceuticals. KW had received speaker honoraria/travel from Genzyme Corporation. AMM and KW had received speaker honoraria/travel from BioMarin Pharmaceuticals

Provenance and peer review Not commissioned; externally peer reviewed. Data sharing statement All data gathered resulted in this publication. 
Open Access This is an Open Access article distributed in accordance with the Creative Commons Attribution Non Commercial (CC BY-NC 4.0) license, which permits others to distribute, remix, adapt, build upon this work non-commercially, and license their derivative works on different terms, provided the original work is properly cited and the use is non-commercial. See: http://creativecommons.org/ licenses/by-nc/4.0/

\section{REFERENCES}

1 Sly WS, Quinton BA, McAlister WH, Rimoin DL. Beta glucuronidase deficiency: report of clinical, radiologic, and biochemical features of a new mucopolysaccharidosis. J Pediatr 1973:82:249-57.

2 Neufeld EF, Muenzer J. The Mucopolysaccharidoses. In: Scriver CR, Beaudet A, Sly WS, et al. eds. The metabolic and molecular basis of inherited disease. Vol III. McGraw-Hill, 2001:3421-52.

3 Nelson J. Incidence of the mucopolysaccharidoses in Northern Ireland. Hum Genet 1997:101:355-8.

4 Pfeiffer RA, Kresse H, Bäumer N, Sattinger E. Beta-glucuronidase deficiency in a girl with unusual clinical features. Eur I Pediatr 1977:126:155-61.

5 Guibaud P, Maire I, Goddon R, Teyssier G, Zabot MT, Mandon G. [Mucopolysaccharidesis Type VII resulting from beta-glucuronidase deficiency. Report of one family]. J Genet Hum 1979;27:29-43.

6 Gitzelmann R, Wiesmann UN, Spycher MA, Herschkowitz N, Giedion A. Unusually mild course of beta-glucuronidase deficiency in two brothers (mucopolysaccharidosis VII). Helv Paediatr Acta 1978:33:413-28.

7 Gehler J, Cantz M, Tolksdorf M, Spranger J, Gilbert E, Drube H. Mucopolysaccharidosis. VII. Beta-glucuronidase deficiency. Humangenetik 1974;23:149-58.

8 Danes BS, Degnan M. Different clinical and biochemical phenotypes associated with b-glucuronidase defficiency. Birth Defects Orig Artic Ser 1974;X:251-7.

9 Beaudet AL, Diferrante NM, Ferry GD, Nichols BL Jr, Mullins CE. Variation in the phenotypic expression of $\beta$-glucuronidase deficiency. J Pediatr 1975;86:388-94

10 Meikle PJ, Hopwood JJ, Clague AE, Carey WF. Prevalence of lysosomal storage disorders. Jama 1999:281:249-54.

11 Applegarth DA, Toone JR, Lowry RB. Incidence of inborn errors of metabolism in British Columbia, 1969-1996. Pediatrics 2000;105:e10.

12 Poorthuis BJ, Wevers RA, Kleijer WJ, Groener JE, de Jong JG, van Weely S, Niezen-Koning KE, van Diggelen OP. The frequency of lysosomal storage diseases in The Netherlands. Hum Genet 1999;105:151-6.

13 Baehner F, Schmiedeskamp C, Krummenauer F, Miebach E, Bajbouj M, Whybra C, Kohlschutter A, Kampmann C, Beck M. Cumulative incidence rates of the mucopolysaccharidoses in Germany. J Inherit Metab Dis 2005;28:1011-17.

14 Malm G, Lund AM, Månsson JE, Heiberg A. Mucopolysaccharidoses in the Scandinavian countries: incidence and prevalence. Acta Paediatr 2008:97:1577-81.

15 Lin HY, Lin SP, Chuang CK, Niu DM, Chen MR, Tsai FJ, Chao MC, Chiu PC, Lin SJ, Tsai LP, Hwu WL, Lin JL. Incidence of the mucopolysaccharidoses in Taiwan, 1984-2004. Am J Med Genet A 2009:149A:960-4.

16 Nelson J, Crowhurst J, Carey B, Greed L. Incidence of the mucopolysaccharidoses in Western Australia. Am J Med Genet A 2003;123A:310-13.

17 Whybra C, Mengel E, Russo A, Bahlmann F, Kampmann C, Beck M, Eich E, Mildenberger $E$. Lysosomal storage disorder in non-immunological hydrops fetalis (NIHF): more common than assumed? Report of four cases with transient NIHF and a review of the literature. Orphanet I Rare Dis 2012;7:86.

18 Muenzer J. Overview of the mucopolysaccharidoses. Rheumatology (Oxford) 2011:50(Suppl 5):v4-12.

19 Stone DL, Sidransky E. Hydrops fetalis: lysosomal storage disorders in extremis. Adv Pediatr 1999;46:409-40.

20 Vervoort R, Islam MR, Sly WS, Zabot MT, Kleijer WJ, Chabas A, Fensom A, Young EP, Liebaers I, Lissens W. Molecular analysis of patients with beta-glucuronidase deficiency presenting as hydrops fetalis or as early mucopolysaccharidosis VII. Am J Hum Genet 1996;58:457-71.

21 Van Dorpe J, Moerman P, Pecceu A, Van den Steen P, Fryns JP. Non-immune hydrops fetalis caused by beta-glucuronidase deficiency (mucopolysaccharidosis VII). Study of a family with 3 affected siblings. Genet Couns 1996;7:105-12.

22 Speleman F, Vervoort R, van Roy N, Liebaers I, Sly WS, Lissens W. Localization by fluorescence in situ hybridization of the human functional beta-glucuronidase gene (GUSB) to $7 q 11.21 \rightarrow q 11.22$ and two pseudogenes to $5 p 13$ and $5 q 13$. Cytogenet Cell Genet 1996;72:53-5.

23 Oshima A, Kyle JW, Miller RD, Hoffmann JW, Powell PP, Grubb JH, Sly WS, Tropak $M$, Guise KS, Gravel RA. Cloning, sequencing, and expression of CDNA for human beta-glucuronidase. Proc Natl Acad Sci USA 1987:84:685-9.

24 Miller RD, Hoffmann JW, Powell PP, Kyle JW, Shipley JM, Bachinsky DR, Sly WS. Cloning and characterization of the human $\beta$-glucuronidase gene. Genomics 1990;7:280-3.

25 Shipley JM, Miller RD, Wu BM, Grubb JH, Christensen SG, Kyle JW, Sly WS. Analysis of the $5^{\prime}$ flanking region of the human beta-glucuronidase gene. Genomics 1991;10:1009-18.
26 Shipley JM, Klinkenberg M, Wu BM, Bachinsky DR, Grubb JH, Sly WS. Mutational analysis of a patient with mucopolysaccharidosis type VII, and identification of pseudogenes. Am J Hum Genet 1993;52:517-26.

27 Wu BM, Tomatsu S, Fukuda S, Sukegawa K, Orii T, Sly WS. Overexpression rescues the mutant phenotype of L176F mutation causing beta-glucuronidase deficiency mucopolysaccharidosis in two Mennonite siblings. J Biol Chem 1994:269:23681-8.

28 Fukuda S, Tomatsu S, Sukegawa K, Sasaki T, Yamada Y, Kuwahara T, Okamoto H, Ikedo Y, Yamaguchi S, Orii T. Molecular analysis of mucopolysaccharidosis type VII. J Inherit Metab Dis 1991:14:800-4.

29 Tomatsu S, Montaño AM, Dung VC, Grubb JH, Sly WS. Mutations and polymorphisms in GUSB gene in mucopolysaccharidosis VII (Sly Syndrome). Hum Mutat 2009:30:511-19.

30 Islam MR, Vervoort R, Lissens W, Hoo JJ, Valentino LA, Sly WS. beta-Glucuronidase P408S, P415L mutations: evidence that both mutations combine to produce an MPS VII allele in certain Mexican patients. Hum Genet 1996;98:281-4.

31 Tomatsu S, Fukuda S, Sukegawa K, Ikedo Y, Yamada S, Yamada Y, Sasaki T, Okamoto H, Kuwahara T, Yamaguchi S, Kiman T, Shintaku H, Isshiki G, Orii T. Mucopolysaccharidosis type VII: characterization of mutations and molecular heterogeneity. Am J Hum Genet 1991;48:89-96.

32 Vervoort R, Buist NR, Kleijer WJ, Wevers R, Fryns JP, Liebaers I, Lissens W. Molecular analysis of the $\beta$-glucuronidase gene: novel mutations in mucopolysaccharidosis type VII and heterogeneity of the polyadenylation region. Hum Genet 1997:99:462-8.

33 Chabas A, Giros ML, Guardiola A. Low beta-glucuronidase activity in a healthy member of a family with mucopolysaccharidosis VII. J Inherit Metab Dis 1991;14:908-14.

34 Vervoort R, Gitzelmann R, Bosshard N, Maire I, Liebaers I, Lissens W. Low beta-glucuronidase enzyme activity and mutations in the human beta-glucuronidase gene in mild mucopolysaccharidosis type VII, pseudodeficiency and a heterozygote. Hum Genet 1998;102:69-78.

35 Hall TA. BioEdit: A user-friendly biological sequence alignment editor and analysis program for Windows 95/98/NT. Nucl Acids Symp Ser 2001;41:95-8.

36 Tamura K, Dudley J, Nei M, Kumar S. MEGA4: Molecular Evolutionary Genetics Analysis (MEGA) Software Version 4.0. Mol Biol Evol 2007;24:1596-9.

37 Dickerman RD, Colle KO, Bruno CA, Jr, Schneider SJ. Craniovertebral instability with spinal cord compression in a 17-month-old boy with Sly syndrome (mucopolysaccharidosis type VII): a surgical dilemma. Spine 2004;29:E92-94.

38 Fox JE, Volpe L, Bullaro J, Kakkis ED, Sly WS. First human treatment with investigational rhGUS enzyme replacement therapy in an advanced stage MPS VII patient. Mol Genet Metab 2015;114:203-8.

39 Hoyme $\mathrm{HE}$, Jones $\mathrm{KL}$, Higginbottom MC, O'Brien JS. Presentation of mucopolysaccharidosis VII (beta-glucuronidase deficiency) in infancy. J Med Genet 1981:18:237-9.

40 Sewell AC, Gehler J, Mittermaier G, Meyer E. Mucopolysaccharidosis type VII (beta-glucuronidase deficiency): a report of a new case and a survey of those in the literature. Clin Genet 1982;21:366-73.

41 Teyssier G, Maire I, Damon G, Boyer S, Lauras B, Freycon F. [Mucopolysaccharidosis type VII. Clinical, radiological and biochemical studies in a neonatal case (author's transl)]. Arch Fr Pediatr 1981;38:603-4.

42 Chabás A, Guardiola A. $\beta$-Glucuronidase deficiency: identification of an affected fetus with simultaneous sampling of chorionic villus and amniotic fluid. Prenat Diagn 1993:13:429-33.

43 Sukegawa K, Orii T. Quantitation and biosynthesis of $\beta$-glucuronidase cross-reactive material in fibroblasts from patients with mucopolysaccharidosis VII. J Inherit Metab Dis 1985;8:145-6.

44 Storch S, Wittenstein B, Islam R, Ullrich K, Sly WS, Braulke T. Mutational analysis in longest known survivor of mucopolysaccharidosis type VII. Hum Genet 2003:112:190-4.

45 Groener JE, de Graaf FL, Poorthuis BJ, Kanhai HH. Prenatal diagnosis of lysosomal storage diseases using fetal blood. Prenat Diagn 1999;19:930-3.

46 Lissens W, Dedobbeleer G, Foulon W, De Catte L, Charels K, Goossens A, Liebaers I. $\beta$-glucuronidase deficiency as a cause of prenatally diagnosed non-immune hydrops fetalis. Prenat Diagn 1991;11:405-10.

47 Irani D, Kim HS, El-Hibri H, Dutton RV, Beaudet A, Armstrong D. Postmortem observations on beta-glucuronidase deficiency presenting as hydrops fetalis. Ann Neurol 1983;14:486-90.

48 Nelson A, Peterson L, Frampton B, Sly WS. Mucopolysaccharidosis VII (B-glucuronidase deficiency) presenting as nonimmune hydrops fetalis. J Pediatr 1982;101:574-6.

49 Kagie MJ, Kleijer WJ, Huijmans JG, Maaswinkel-Mooy P, Kanhai HH. beta-Glucuronidase deficiency as a cause of fetal hydrops. Am J Med Genet 1992:42:693-5.

50 Molyneux AJ, Blair E, Coleman N, Daish P. Mucopolysaccharidosis type VII associated with hydrops fetalis: histopathological and ultrastructural features with genetic implications. J Clin Pathol 1997:50:252-4.

51 Nelson J, Kenny B, O'Hara D, Harper A, Broadhead D. Foamy changes of placental cells in probable beta glucuronidase deficiency associated with hydrops fetalis. J Clin Pathol 1993;46:370-1. 
52 Stangenberg M, Lingman G, Roberts G, Ozand P. Mucopolysaccharidosis VII as cause of fetal hydrops in early pregnancy. Am J Med Genet 1992;44:142-4.

53 Van Eyndhoven HW, Ter Brugge HG, Van Essen AJ, Kleijer WJ. $\beta$-glucuronidase deficiency as cause of recurrent hydrops fetalis: the first early prenatal diagnosis by chorionic villus sampling. Prenat Diagn 1998;18:959-62.

54 Yamada S, Tomatsu S, Sly WS, Islam R, Wenger DA, Fukuda S, Sukegawa K, Orii T. Four novel mutations in mucopolysaccharidosis type VII including a unique base substitution in exon 10 of the $\beta$-glucuronidase gene that creates a novel $5^{\prime}$-splice site. Hum Mol Genet 1995;4:651-5.

55 Kooper AJ, Janssens PM, de Groot AN, Liebrand-van Sambeek ML, van den Berg CJ, Tan-Sindhunata GB, van den Berg PP, Bijlsma EK, Smits AP, Wevers RA. Lysosomal storage diseases in non-immune hydrops fetalis pregnancies. Clin Chim Acta 2006;371:176-82.

56 Saxonhouse MA, Behnke M, Williams JL, Richards D, Weiss MD. Mucopolysaccharidosis Type VII presenting with isolated neonatal ascites. J Perinatol 2003;23:73-5.

57 Capdeville R, Boissinot G, Graveleau D, Maroteaux P. [A new case of mucopolysaccharidosis type VII with major skeletal abnormalities]. Ann Pediatr (Paris) 1983;30:689-92.

58 Gillett PM, Schreiber RA, Jevon GP, Israel DM, Warshawski T, Vallance $H$, Clarke LA. Mucopolysaccharidosis type VII (Sly syndrome) presenting as neonatal cholestasis with hepatosplenomegaly. J Pediatr Gastroenterol Nutr 2001;33:216-20.

59 Nampoothiri S, Kappanayil M, Hiran KR, Sunitha V. Sly Disease: Mucopolysaccharidosis Type VII. Indian Pediatr 2008;45:859-61.

60 Toda Y, Takeuchi M, Morita K, Iwasaki T, Oe K, Yokoyama M, Hirakawa M. Complete heart block during anesthetic management in a patient with mucopolysaccharidosis type VII. Anesthesiology 2001;95:1035-7.

61 Young RD, Liskova P, Pinali C, Palka BP, Palos M, Jirsova K, Hrdlickova E, Tesarova M, Elleder M, Zeman J, Meek KM, Knupp C, Quantock AJ. Large proteoglycan complexes and disturbed collagen architecture in the corneal extracellular matrix of mucopolysaccharidosis type VII (Sly syndrome). Invest Ophthalmol Vis Sci 2011;52:6720-8.

62 Vogler C, Levy B, Kyle JW, Sly WS, Williamson J, Whyte MP. Mucopolysaccharidosis VII: postmortem biochemical and pathological findings in a young adult with beta-glucuronidase deficiency. Mod Pathol 1994;7:132-7.

63 Gniadek TJ, Singer N, Barker NJ, Spevak PJ, Crain BJ, Valle D, Halushka MK. Cardiovascular pathologies in mucopolysaccharidosis type VII (Sly Syndrome). Cardiovasc Pathol 2015;24:322-6.

64 Pizzutillo PD, Osterkamp JA, Scott Cl, Jr, Lee MS. Atlantoaxial instability in mucopolysaccharidosis type VII. J Pediatr Orthop 1989;9:76-8.

65 de Kremer RD, Givogri I, Argaraña CE, Hliba E, Conci R, Boldini CD, Capra AP. Mucopolysaccharidosis type VII (beta-glucuronidase deficiency): a chronic variant with an oligosymptomatic severe skeletal dysplasia. Am J Med Genet 1992:44:145-52.

66 Tokieda K, Morikawa Y, Natori M, Hayashida S, Mori K, Ikeda K. Intrauterine growth acceleration in the case of a severe form of mucopolysaccharidosis type VII. J Perinat Med 1998;26:235-9.

67 White KK. Orthopaedic aspects of mucopolysaccharidoses. Rheumatology (Oxford) 2011;50(Suppl 5):v26-33.
68 Wallace SP, Prutting CA, Gerber SE. Degeneration of speech, language, and hearing in a patient with mucopolysaccharidosis VII. Int J Pediatr Otorhinolaryngol 1990;19:97-107

69 O'Connor LH, Erway LC, Vogler CA, Sly WS, Nicholes A, Grubb J, Holmberg SW, Levy B, Sands MS. Enzyme replacement therapy for murine mucopolysaccharidosis type VII leads to improvements in behavior and auditory function. J Clin Invest 1998;101:1394-400.

70 Vogler C, Levy B, Grubb JH, Galvin N, Tan Y, Kakkis E, Pavloff N, Sly WS. Overcoming the blood-brain barrier with high-dose enzyme replacement therapy in murine mucopolysaccharidosis VII. Proc Natl Acad Sci USA 2005;102:14777-82.

71 Huynh HT, Grubb JH, Vogler C, Sly WS. Biochemical evidence for superior correction of neuronal storage by chemically modified enzyme in murine mucopolysaccharidosis VII. Proc Natl Acad Sci USA 2012;109:17022-7.

72 Rowan DJ, Tomatsu S, Grubb JH, Haupt B, Montano AM, Oikawa H, Sosa AC, Chen A, Sly WS. Long circulating enzyme replacement therapy rescues bone pathology in mucopolysaccharidosis VII murine model. Mol Genet Metab 2012;107:161-72.

73 Sands MS, Vogler C, Torrey A, Levy B, Gwynn B, Grubb J, Sly WS, Birkenmeier EH. Murine mucopolysaccharidosis type VII: long term therapeutic effects of enzyme replacement and enzyme replacement followed by bone marrow transplantation. J Clin Invest 1997;99:1596-605.

74 Liu G, Chen YH, He X, Martins I, Heth JA, Chiorini JA, Davidson BL. Adeno-associated virus type 5 reduces learning deficits and restores glutamate receptor subunit levels in MPS VII mice CNS. Mol Ther 2007;15:242-7.

75 Mango RL, Xu L, Sands MS, Vogler C, Seiler G, Schwarz T, Haskins ME, Ponder KP. Neonatal retroviral vector-mediated hepatic gene therapy reduces bone, joint, and cartilage disease in mucopolysaccharidosis VII mice and dogs. Mol Genet Metab 2004;82:4-19.

76 Fox JE, Volpe L, Bullaro J, Kakkis E, Sly WS. A one year follow-up of treatment with investigational recombinant human beta-glucuronidase enzyme replacement in a patient with an advanced stage mucopolysaccharidosis type VII. Mol Genet Metab 2015;114:359.

77 Valayannopoulos $\mathrm{V}$, Wijburg FA. Therapy for the mucopolysaccharidoses. Rheumatology (Oxford) 2011;50(Suppl 5):v49-59.

78 Birkenmeier EH, Barker JE, Vogler CA, Kyle JW, Sly WS, Gwynn B, Levy B, Pegors C. Increased life span and correction of metabolic defects in murine mucopolysaccharidosis type VII after syngeneic bone marrow transplantation. Blood 1991;78:3081-92.

79 Birkenmeier EH, Davisson MT, Beamer WG, Ganschow RE, Vogler CA, Gwynn B, Lyford KA, Maltais LM, Wawrzyniak CJ. Murine mucopolysaccharidosis type VII. Characterization of a mouse with beta-glucuronidase deficiency. J Clin Invest 1989:83:1258-66.

80 Yamada Y, Kato K, Sukegawa K, Tomatsu S, Fukuda S, Emura S, Kojima S, Matsuyama T, Sly WS, Kondo N, Orii T. Treatment of MPS VII (Sly disease) by allogeneic BMT in a female with homozygous A619V mutation. Bone Marrow Transplant 1998;21:629-34.

81 Bailey L. An overview of enzyme replacement therapy for lysosomal storage diseases. Online J Issues Nurs 2008;13:4.

82 Sands MS, Barker JE, Vogler C, Levy B, Gwynn B, Galvin N, Sly WS, Birkenmeier E. Treatment of murine mucopolysaccharidosis type VII by syngeneic bone marrow transplantation in neonates. Lab Invest 1993;68:676-86. 